Kastamonu Eğitim Dergisi
$\begin{aligned} & \text { Kastamonu Education Journal } \\ & \text { Ocak 2020 Cilt:28 Sayı:1 } \\ & \text { kefdergi.kastamonu.edu.tr }\end{aligned}$

\title{
Öğretmenlerin Mesleklerinin İlk Yıllarında Sınıf Yönetiminde Yaşadıkları Sorunlara İlişkin Görüşlerinin Değerlendirilmesi
}

\section{Evaluation of Teachers' Views on Problems in Classroom Management in Their Early Years}

\author{
Öz \\ Serdar BOZAN ${ }^{1}$, Abdurrahman EKINCi²
}

Bu çalışmada; mesleklerinin ilk yıllarında öğretmenlerin sınıf yönetimine ilişkin yaşadıkları zorlukları ve süreç içerisinde kazandıkları tecrübeleri belirlemekle beraber göreve yeni başlayan öğretmen adayları için sınıf yönetimine yönelik önerileri alınmaya çalışıımıştır. Araştırma tarama türünde nitel bir çalışmadır. Bu amaçla 2016-2017 eğitim ve öğretim yılında, Mardin Artuklu ilçesinde, farklı kademe, okul türü ve branştan amaçıı örnekleme tekniklerinden maksimum çeşitlilik örneklemesi tekniği ile belirlenen 64 öğretmen ile çalışma grubu oluşturulmuştur. Çalışmaya katılan öğretmenlere veri toplama formları dağıtılarak toplanmıştır. Elde edilen veriler içerik analizine tabi tutularak, bulgular; tema, alt tema/görüş ve frekanslarla birlikte tablolar halinde sunulmuştur. Çalışma bulguları incelendiğinde öğretmenlerin sınıf yönetiminde genel olarak öğretmen yeterlilik/özelliklerinden kaynaklı (öğrenci dikkatinin canlı tutulması, öğretmen alan yetersizliği...) öğrencilerden kaynakı (öğrencilerin derse hazırlıksız gelmesi, öğrenci hazırbulunuşluk durumları, belirlenen kuralların ihlal edilmesi...), velilerden kaynakı (sosyal ve kültürel farklııklar, veli tutumları), mekandan kaynaklı (fiziki şartların yetersizliği, sınıfların kalabalık olması) hususlarda sorun yaşadıkları tespit edilmiştir. Göreve yeni başlayan öğretmen adayları için sınıf yönetimine yönelik önerilerin ise öğretmen yeterliliklerinin geliştirilmesi, uygun sınıf ikliminin oluşturulması, farklı yöntem-teknik kullanımı ve mekanın düzenlenmesi hususlarında olduğu görülmüştür.

Anahtar Kelimeler: öğretmen, sınıf yönetimi, sınıf yönetimi becerisi

\section{Abstract}

In this study, it has been tried to determine the difficulties experienced by the teachers in the first years of their professions about the classroom management and the experiences they gained in the process, and it has been tried to take suggestions for the classroom management for the new teacher candidates. For this purpose, in 2016-2017 academic year, a working group was formed with 64 teachers who were determined by the maximum diversity sampling technique from the different stage, type of school and branched sampling techniques in Mardin-Artuklu. Data collection forms were distributed to the teachers who participated in the study. The data has been subjected to content analysis. The findings have been presented in tables with theme, sub-theme / views and frequencies. When the study findings were examined, it was determined that the teachers experienced problems in classroom management due to the teacher qualification / characteristics (keeping student attention alive, lack of teacher space ...), originating from students (students come to the class unprepared, student readiness status, violation of the determined rules...), originating from parents (social and cultural differences, parent attitudes), and due to place (lack of physical conditions, crowded classes). Suggestions for classroom management for newly recruited teacher candidates have been found as development of teacher qualifications, creation of appropriate classroom climate, use of different methods and techniques, and the organization of place

Keywords: teacher, classroom management, classroom management skills

\footnotetext{
${ }^{1}$ Milli Eğitim Bakanlığı, Türkiye, https://orcid.org/0000-0002-1677-4727

${ }^{2}$ Artuklu Üniversitesi, Edebiyat Fakültesi, Eğitim Bilimleri Anabilim, Mardin, Türkiye, https://orcid.org/0000-0002-1545-1379

Atıf / Citation: Bozan, S. ve Ekinci, A. (2020). Öğretmenlerin Mesleklerinin Illk Yıllarında Sınıf Yönetiminde Yaşadıkları Sorunlara ilişkin Görüşlerinin Değerlendirilmesi. Kastamonu Education Journal, 28(1), 137-153. doi:10.24106/kefdergi.3480
} 


\section{Extended Abstract}

Introduction: In education activities, the first condition of achieving the expected success is seen as an effective clasroom management (Aytekin, 2007). The effectiveness of classroom management depends on the organization and management of classroom activities (Ayaydın, 2010). Good organizing and management of classroom activities is possible with a teacher who is equipped with all aspects. Although it may be difficult to apply the theoretical knowledge of classroom management in the first years of the profession, it is partially possible that the theoretical knowledge may be practiced and combined with experience.

Aim: The problems experienced by experienced teachers in eliminating these errors and problems and their basic approaches and suggestions are critically important. In this study, the opinions of experienced teachers in their profession were taken for this purpose and especially the problems they encountered in the context of classroom management in the first years of the profession and the suggestions of the teachers who will start to the profession has been tried to be obtained.

Method: Research is a qualitative study of the type of screening. The screening model is a study model which aims to collect data to determine the specific characteristics of a group (Büyüköztürk, Çakmak, Akgün, Karadeniz and Demirel, 2009). Semi-structured questionnaire was prepared as data collection tool. The open-ended questions were examined by the faculty member who was expert in the field in terms of their comprehensibility and suitability for the purpose of the research and necessary arrangements were made in line with the suggestions.

Result: When the findings of the study are examined, it has been observed that teachers have problems based on mainly the teacher qualifications / characteristics of the teachers (keeping the attention of the students alive, lack of teachers in the field ...), parents (social and cultural differences, parent attitudes), location (lack of physical conditions, crowded classes) in class management. Suggestions for newly recruited teachers have been seen as the development of teacher qualifications, creation of appropriate classroom climate, different methods-techniques, and the organization of space. 


\section{Giriş}

Toplumsal ve ekonomik kalkınma ile refahın en önemli dinamosu nitelikli bir eğitimdir. Bu çerçevede nitelikli bir eğitim sisteminin de en önemli aktörü kuşkusuz kaliteli ve çağın gerektirdiği donanıma sahip öğretmenlerdir (Vural, 2004). Öğretmenlerin kişilik, alan bilgisi, öğretim becerileri ve mesleki yeterliliklerinin sınıf içerisinde etkin şekilde yansımasında ise sınıf yönetimi becerileri belirleyici bir role sahiptir. Öğretmenlik mesleğine dair nitelikte meslek öncesi yetiştirme önemli olmakla birlikte öğretmenlik mesleğine ilişkin deneyim ve temel beceriler sınıf içerisinde ve mesleğin ilk yıllarında daha yoğun şekilde elde edilmektedir. Bu süreçte deneme ve yanılmalar birçok soruna da neden olabilmektedir. Özellikle öğretmenlik mesleğinin ilk yılları ve bu süreçte yaşanan sorunların öğretmenin meslekte kalıp kalmaması ve mesleğe karşı geliştirdiği tutum ve temel yaklaşımını belirleyici kritik dönem olarak ifade edilmektedir (Karge, 1993; Ergenekon, 2004). Öğretmenlikte, mesleğin ilk yıllarında karşılaşılan en önemli sorunlardan birinin sınıf yönetimi olduğunu söylemek mümkündür (Akın ve Koçak, 2007; Alkan, 2007; Recepoğlu ve Ergün, 2017). Bu sorunların öğretimin niteliği ve mesleğe uyum sağlama gibi birtakım kritik süreçleri belirleyici nitelikte olduğu söylenebilir.

Sınıf yönetimi, öğretmenin öğreticilik yönünün sınıf içi yöneticilik özellikleri üzerine inşa edilip harmanlandığı, teorinin pratiğe dönüştüğü bir süreçtir. Bu süreç; Celep'e (2002) göre eğitimin amacını gerçekleştirmek için sınıfın öğretim kaynaklarını ve öğrencileri eşgüdümleyerek harekete geçirme süreci, Evertson ve Weinstein'a (2006) göre bir öğretmenin hem akademik hem de sosyal ve duygusal öğrenmeyi kolaylaştıran ve destekleyen bir çevre yaratmak için gerekli her türlü eylem, Sarıçoban'a (2005) göre çok farklı çevrelerden gelen insanları tek bir hedefe yöneltmektir. Bu bakımından etkili bir sınıf yönetiminin en önemli unsuru öğretmendir. Ayrıca, öğretmen sınıf yönetimi anlayışını şekillendirmenin yanı sıra yürütücüsü rolüne de sahiptir. Öğretmenin bu rolleri gerçekleştirme düzeyi doğrudan eğitimin kalitesinde belirleyici olabilmektedir. Bu nedenle Demirtaş (2009) öğretmenin eğiticilik özelliği kadar yöneticilik özelliğinin de geliştirilmesi gerektiğini vurgulamıştır. Bu becerinin öğretmenlik mesleğinin ilk yıllarında hemen kazanılacak bir beceri olduğunu söylemek güçtür. Aynı şekilde Ilgar (2007) sınıf yönetimi becerisinin kazanılmasının, zaman alan bir beceri olduğunu vurgulamıştır. Yapılan araştırmalarda da öğretmenlik mesleğinin ilk yıllarında öğretmenlerin sınıf yönetimi konusunda önemli sorunlar yaşadıkları (Taşdan ve Kantos, 2007), hatta bu nedenle işi bırakmak durumunda kaldıkları durumlarla da karşılaşılmıştır (Phelps, 1991).

Öğretmenin sınıf yönetimine ilişkin sahip olması gereken beceriler konusunda farklı sınıflandırmalar mevcut olup bu beceriler, Gündüz (2004) tarafından; sınıf ortamının fiziksel düzeni, plan- program, sınıf içi ilişkiler, davranış düzeni ve zaman kullanımı şeklinde beş boyutta sınıflandırılmıştır. Lemlech (1991) ise; sınıf ortamının düzenlenmesi, öğretimin programlanması, kaynakların organize edilmesi, sınıf çevresinin etkililiğini en üst düzeye çıkaracak şekilde düzenlenmesi, öğrenci gelişimine rehberlik ve sınıf içi oluşabilecek problemlere yönelik önlemler şeklinde boyutlandırmıştır. Sınıf yönetimi yaklaşımlarına bakıldığında Rogers ve Freiberg'in (1994) öğretmen merkezli ve öğrenci merkezli yaklaşımları yanı sıra klasik (geleneksel), sosyal, kültürel, bilimsel ve teknolojik gelişmeler sonrası oluşan modern (çağdaş) yönetim anlayışı mevcuttur (Yüksel, 2013). Klasik yaklaşım daha çok öğretmen merkezli olup, öğretmenin belirlediği katı kurallar ve uygulamalar barındıııken, modern yaklaşımda ise öğrenci merkezli bir anlayış hâkimdir. Klasik yaklaşımın öğretmen merkezli olması ve süreci yönlendiren kişinin öğretmen olması nedeniyle öğretmen bilgi, beceri, tutum ve davranış açısından fazla zorlanmazken, modern yaklaşımın öğrenci merkezli olması, bilgi, beceri, tutum ve davranış yönünden öğrencinin gerisinde kalmamasını gerektirdiği için her yönüyle donanımlı öğretmen ihtiyacının önem taşıdığını söylemek mümkündür.

Sınıf yönetimi yaklaşımlarında olduğu gibi sınıf yönetimi modellerinin de toplumsal gelişmelere bağlı olarak baskıcı modelden demokratik modele, şekilsellikten hedef yönelimliye, öğretmen merkezli anlayıştan öğrenci merkezli anlayışa evrildiği görülmüştür (Başar, 1999). Bu modeller (Malmgren, Trezek ve Paul, 2005; Mannig ve Bucher, 2014) durumu veya davranışı gerçekleştirmek, önlemek için ödül veya cezanın kullanıldığı tepkisel model, istenmeyen davranışın oluşumundan önce önleme ilkesine dayanan önlemsel model, öğrencinin bedensel, ruhsal gelişim düzeyinin dikkate alınarak hareket edildiği gelişimsel model, hem tepkisel, hem önlemsel, hem de gelişimsel yaklaşımın koordineli bir şekilde kullanıldığı bütünsel modeldir (Başar, 2008; Erdoğan, 2011; Sarıtaş, 2003; Yılmaz, 2008). Her ne kadar modeller çeşitlilik gösterse de her ortamda en verimli ve etkili sınıf yönetimini yaklaşımından/modelinden söz etmek mümkün değildir. Kullanılacak modeli/yaklaşımı belirleyecek olan faktörler; ortam, ulusal ve yerel kültür, öğrenci düzeyi ve sınıfın yapısıdır (Gökalp ve Gönülal, 2017). Öğretmen bu modellerden birini esas alabileceği gibi zaman ve duruma göre birçok yaklaşımdan da yararlanabilir (Demirtaş, 2006). Sınıf yönetimi ve özellikle sınıf yönetiminde yaşanan sorunlara dair alan yazınında birçok çalışma mevcuttur (Aküzüm ve Nazlı, 2017; Erol, Özaydın ve Koç, 2010; Kırbaş ve Atay, 2017; Merrett ve Wheldall, 1993). Ancak, bu çalışmada sınıf yönetiminin deneyimsel ve 
davranışsal bir beceriler bütünü gerektirmesi gerçeğinden yola çıkılmıştır. Özellikle mesleklerinin ilk yıllarında karşılaşılan sorunlar ve deneyime dayalı olarak elde edilen temel beceri ve davranışlar ile bu bağlamdaki önerilerin neler olduğunu doğrudan bu deneyimi yaşayan öğretmen görüşleri doğrultusunda belirlenmeye çalışılacaktır.

\section{Araştırmanın Amacı}

Sınıf yönetimine ilişkin söz konusu hataları ve problemleri ortadan kaldırmada deneyimli öğretmenlerin yaşadıkları sorunlar ve temel yaklaşımları ile önerileri oldukça kritik değer taşımaktadır. Bu çalışmada söz konusu amaca yönelik olarak mesleğinde deneyimli öğretmenlerden görüş alınmış, özellikle meslekteki ilk yıllarında sınıf yönetimi bağlamında karşılaştıkları sorunlar ve mesleğe yeni başlayacak öğretmenlere önerileri elde edilmeye çalışılmıştır. Bu temel amaç doğrultusunda aşağıdaki alt problemlere cevap aranmıştır;

1- Öğretmeni sınıf yönetiminde en çok zorlayan hususlar nelerdir?

2- Öğretmenlerin, öğretmenliğin ilk dönemleri ile kıyaslandığında sınıf yönetimi becerileri ne düzeyde gelişmiştir?

3- Meslek hayatında sınıf yönetiminde daha önce yapılan ve hata olarak değerlendirilen; deneyim kazandıkça farklı tutum ve davranış geliştirilen hususlar nelerdir?

4- Mesleğe yeni başlayan bir öğretmene, sınıf yönetimine ilişkin tavsiyeler nelerdir?

\section{Yöntem}

Araştırma tarama türünde nitel bir çalışmadır. Tarama modeli bir grubun belirli özelliklerini belirlemek için verilerin toplanmasını amaçlayan (Büyüköztürk, Çakmak, Akgün, Karadeniz ve Demirel, 2009) çalışma modelidir. Veri toplama aracı olarak yarı yapılandırılmış soru formu hazırlanmıştır. Hazırlanan açık uçlu sorular anlaşılırlığı ve araştırma amacına uygunluğu açısından alanda uzman öğretim üyesine incelettirilmiş ve öneriler doğrultusunda gerekli düzenlemeler yapılmıştır.

\section{Çalışma Grubu}

Araştırmanın çalışma grubu 64 öğretmenden oluşmaktadır. Çalışma grubunun belirlenmesinde amaçlı örnekleme tekniklerinden maksimum çeşitlilik örneklemesi tekniği kullanılmıştır. Maksimum çeşitlilik örneklemesindeki amaç, göreli olarak küçük bir örneklem oluşturmak ve bu örneklemde çalışılan probleme taraf olabilecek bireylerin çeşitliliğini maksimum derecede yansıtmaktır (Yıldırım ve şimşek, 2006). Bu tekniğin seçilmesindeki amaç, birtakım farklııkları içeren temel temaları bulup yorumlamaya olanak vermesidir (Patton, 2014). Bir başka deyişle, farklı özelliklere sahip katılımcılardan daha zengin verilerin alınmasını sağlayabilecek bir yaklaşım olarak ifade edilebilir. Bu nedenle maksimum çeşitlilik örneklemesi yapılırken incelenen olguya ilişkin en fazla bilgi edinilecek etkenler belirlenir (Neuman ve Robson, 2014). Aşağıdaki Tablo 1'de araştırmaya katılan öğretmenlere ilişkin bilgiler verilmiştir.

Tablo 1. Öğretmen Demografik Özellikleri

\begin{tabular}{lccccc}
\hline \multirow{2}{*}{ Okul Türü } & Okul Sayısı & \multicolumn{2}{c}{ Alan } & \multicolumn{2}{c}{ Cinsiyet } \\
\cline { 3 - 6 } & & Sını Öğrt. & $\begin{array}{l}\text { Branş } \\
\text { Öğrt. }\end{array}$ & Kadın & Erkek \\
\hline Illkokul & 4 & 26 & - & & \\
Ortaokul & 3 & - & 18 & 28 & 36 \\
Genel Lise & 3 & - & 12 & & \\
Meslek Lisesi & 1 & - & 8 & 64 & \\
Toplam & 11 & & 64 & & 6 \\
\hline
\end{tabular}

Tablo 1'e göre; her kademe türünde eşit şekilde okul belirlenmeye (ilkokul:4, ortaokul:3, lise:4) çalışımıştır. Alan bazında öğretmen dağılımı sınıf öğretmeni (f:26), branş öğretmeni (f:38) şeklinde gerçekleşerek branş 
öğretmenlerinin daha fazla olduğu görülmüştür. Cinsiyet dağıımı açısından erkek öğretmenlerin (f:36), kadın öğretmenlerden (28) daha fazla oldukları bulgulanmıştır.

\section{Veri Toplama Aracı ve Uygulanması}

Veri toplama aracı olarak dört sorudan oluşan bir yarı yapılandırılmış soru formu hazırlanmış ve alanda uzman bir öğretim üyesince incelenmiş ve öneriler doğrultusunda forma son hali verilmiştir. 2016-2017 Kasım-Aralık aylarında ulaşılan okullarda mevcut öğretmenlerle görüşülerek araştırmanın amacı ve veri toplama aracı hakkında bilgi verilmiştir. Ardından çalışmaya katııımda gönüllülük gösteren öğretmenlere veri toplama araçları dağıtılarak aynı gün içerisinde kendilerinden teslim alınmıştır. Araştırmaya 73 öğretmen katılmış, ancak 9 öğretmenin doldurduğu formlar yeterli veri içermediğinden elenmiş, 64 öğretmen görüşü geçerli sayılmıştır.

\section{Verilerin Analizi}

Görüş alma formlarında yer alan veriler içerik analizine tabi tutulmuştur. Veriler analiz edilirken şu aşamalar takip edilmiştir: 1- Verilerin Kodlanması 2- Kodlanan Verilerin Temalarının Belirlenmesi 3- Kod ve Temaların Düzenlenmesi 4- Bulguların Tanımlanması ve Yorumlanması şeklindedir(Yıldırım ve Şimşek, 2013). Analiz birimi olarak cümleler seçilmiş ve tablolara aktarılarak frekanslarla birlikte sunulmuştur. Bu süreçte öğretmenlere (Ö1, Ö2...) şeklinde kodlar verilmiştir. Öğretmenlerin cevapları doğrultusunda, cevapların benzerliğine göre gruplamalar yapılmıştır. Ortaya çıkan görüşler temalar altında gruplanmıştır. Son olarak, kodlar ve alıntılar temalar altında verilmiş ve yorumlanmıştır.

\section{Geçerlilik ve Güvenirlik}

Elde edilen bulguların gerçeği yansıtabilmesi geçerlik, bu bulguların tutarlılığı ve tekrar edilebilirliği ise güvenirlik olarak tanımlanmaktadır (Yıldırım ve Şimşek, 2013). Bu araştırmanın geçerlilik ve güvenirliliğini sağlamak amacıyla; a) içerik analizinde her bir görüş formunu araştırmacıların her ikisi ayrı ayrı inceleyerek elde edilen analiz birimlerini karşılaştırmış ve farklı ifadelerin yer aldığı durumlarda söz konusu veri toplama aracı birlikte incelenerek ilgili analiz birimi yeniden düzenlenmiş, b) elde edilen veriler analiz edildikten sonra katılımcı teyidi için öğretmenlerin görüşlerine sunulmuş ve görüşlerini yansıtığına dair onayları alınmış, c) birden fazla kodlayıcı tarafından kodlanan veri setinin benzerlik oranları araştırmacıların bireysel etkisinden arındırıması ve güvenirliliği belirlemek açısından önemlidir (Fidan ve Öztürk, 2015). Miles ve Huberman tarafından geliştirilen iç tutarlılık modeli ile kodlayıcılar arasındaki görüş birliği formülleştirilmiş ve bu hesaplama sonrası görüş birliğinin en az \%80 olması beklenmiştir (Miles ve Huberman, 1994). Bu amaçla çalışmada oluşturulan veri seti alanda uzman bir akademisyene inceletilmiş ve kodlayıcılar arası görüş birliği \%91 olarak hesaplanmıştır.

\section{Bulgular}

Çalışmanın bu bölümünde çalışmaya ilişkin bulgular, temalar ve bu temalara dair alt temalar olarak dört tablo halinde sunulmuştur.

\section{1 Öğretmeni Sınıf Yönetiminde En Çok Zorlayan Hususlara Iliş̧kin Görüşler}

Öğretmeni sınıf yönetiminde en çok zorlayan hususlara ilişkin görüşler 5 tema ve bu temalara ilişkin 26 alt tema/görüş frekanslarıyla birlikte Tablo 2'de sunulmuştur.

Tablo 2. Öğretmeni Sınıf Yönetiminde En Çok Zorlayan Hususlara iliş̧kin Görüşleri

\begin{tabular}{|c|c|c|c|c|c|c|c|}
\hline No & Tema & Alt Tema & $f$ & No & Tema & Alt Tema & $f$ \\
\hline 1 & $\begin{array}{l}\text { Öğretmen } \\
\text { Özellikleri }\end{array}$ & $\begin{array}{l}\text { Öğrenci Dikkatini Canlı } \\
\text { Tutma }\end{array}$ & 9 & 1 & $\begin{array}{l}\text { Öğrenci } \\
\text { Özellikleri }\end{array}$ & Haylaz ve Yaramaz Öğrenciler & 13 \\
\hline 2 & & Öğretmen Yetersizliği & 5 & 2 & & $\begin{array}{l}\text { Öğrenci Hazır bulunuşluk } \\
\text { Seviyelerinin Düşük Olması }\end{array}$ & 9 \\
\hline 3 & & $\begin{array}{l}\text { Teknolojiyi } \\
\text { Kullanamama }\end{array}$ & 2 & 3 & & $\begin{array}{l}\text { Öğrencilerin Derse Hazırlıksız } \\
\text { Gelmesi }\end{array}$ & 6 \\
\hline 4 & & $\begin{array}{l}\text { Ögrenciyi İyi } \\
\text { Tanımamaktan Kaynaklı } \\
\text { Hatalar }\end{array}$ & 2 & 4 & & Ögrencilerin Saygısız Davranışları. & 6 \\
\hline
\end{tabular}


Tablo 2'nin devamı

\begin{tabular}{|c|c|c|c|c|c|c|c|}
\hline No & Tema & Alt Tema & $f$ & No & Tema & Alt Tema & $f$ \\
\hline 5 & & $\begin{array}{l}\text { Dersi Tüm Öğrencilere } \\
\text { Yönelik Anlatabilme }\end{array}$ & 2 & 5 & & Kuralların Ihlal Edilmesi & 5 \\
\hline 6 & & $\begin{array}{l}\text { Öğrenci ile Mesafeyi } \\
\text { Koruyamama }\end{array}$ & 2 & 6 & & Sivrilen Çocuklar & 4 \\
\hline 7 & & $\begin{array}{l}\text { Ses Seviyesini İyi } \\
\text { Ayarlayamama }\end{array}$ & 1 & 7 & & Davranış Kontrolü & 4 \\
\hline 8 & & Iletişimsizlik & 1 & 8 & & Öğrenci Problemleri & 3 \\
\hline 9 & & Zaman Kullanımı & 1 & 9 & & Ahlaki Zafiyet & 2 \\
\hline 10 & & $\begin{array}{l}\text { Öğretmenin Kıllı- } \\
\text { Kıyafeti }\end{array}$ & 1 & 10 & & $\begin{array}{ll}\text { Özel Eğitim } & \text { Gerektirecek } \\
\text { Öğrencilerin Olması } & \end{array}$ & 2 \\
\hline 11 & Program & Programın Ağır Olması. & 11 & 11 & & $\begin{array}{l}\text { Öğrencilerin Sorumluluklarını } \\
\text { Yerine Getirmemesi }\end{array}$ & 1 \\
\hline 1 & Veli & Veli Tutumları & 17 & 1 & Mekan & Fiziki Şartların Yetersizliği & 15 \\
\hline 2 & & $\begin{array}{l}\text { Sosyal ve Kültürel } \\
\text { Farklılıkları }\end{array}$ & 6 & 2 & & Sınıfların Kalabalık Olması & 14 \\
\hline
\end{tabular}

Tablo 2'de öğretmenleri sınıf yönetiminde en çok zorlayan hususlardan “Öğretmen Özellikleri” temasında dikkat çeken alt tema/görüşler; öğrenci dikkatini canlı tutma ( $f: 9)$, öğretmen alan yetersizliği ( $f: 5)$, teknolojiyi etkin kullanamama (f:2), öğrenciyi iyi tanıyamama (f:2), tüm öğrencilere yönelik anlatabilme (f:2), öğrenci ile mesafeyi koruyamama (f:2), ses seviyesini ayarlayamama (f:1), iletişimsizlik (f:1), zaman kullanımı (f:1), öğretmenin kılık kıyafeti (f:1) gibi hususlardır. "Program" temasında dikkat çeken alt tema; programın ağır olması (f:11). "Veli" temasında dikkat çeken alt temalar; veli tutumları (f:17), sosyal ve kültürel farklııklar (f:6). "Öğrenci Özellikleri" temasında dikkat çeken alt temalar; haylaz ve yaramaz öğrenciler (f:13), öğrenci hazır bulunuşluk seviyelerinin düşük olması (f:9), öğrencilerin derse hazırıksız gelmesi (f:6), öğrencilerin saygısız davranışları (f:6), kuralların ihlal edilmesi $(f: 5)$, sivrilen ve davranışlarını kontrol edemeyen öğrenciler (f:4), öğrenci problemleri ( $f: 3)$, özel eğitim gerektiren öğrenciler ve ahlaki zafiyet (f:2), öğrencilerin sorumluluklarını yerine getirmemesi (f:1). "Mekan" temasında dikkat çeken alt temalar ise; fiziki şartların yetersizliği (f:15), sınıfların kalabalık olması (f:14).

Sınıf yönetiminde öğretmenleri en çok zorlayan hususların başında "öğrenci dikkatini canlı tutma" geldiği görülmektedir. Ö25 no'lu öğretmen "Öğrencileri sürekli canlı tutmak derslere dikkatini dağıtmamak bir öğretmen için zordur. Bu yüzden öğretmenin ders alanıyla ilgili ilginç hikayeler anlatması ya da dikkat çekici sorular sorarak dersi ilginç hale getirmek öğretmenin elindedir" şeklinde görüş ifade etmiştir. Öğretmenler, öğrencilerin dikkatini çekmenin zor olduğunu, sınıf yönetimini çeşitli şekillerde sağlamanın yollarını önermiş ve öğretmen yeterliliğine de dikkat çekmişlerdir. Öğretmenlerin sınıf yönetiminde en çok zorlandıkları ikinci husus ise "öğretmen alan yetersizliği" yönündedir. Ö11no'lu öğretmen bu yetersizliği "eğitim fakülteleri derslerinin içlerinin boşaltılması dolayısıyla, yöntem, teknik ve bunların uygulanmasından habersiz yetersiz öğretmen yetiştirilmesi" şeklinde sorunu, lisans sürecinde alınan eğitimin yetersizliğine bağlamaktadır. Alan yeterliliği içerisinde yer alan önemli bir nokta da öğretmenin hızla gelişen teknoloji karşısında kendini yenileyebilmesi ve geliştirebilmesidir. Teknolojinin ders sırasında etkin kullanımına ilişkin Ö11 no'lu öğretmenin görüşü "Teknolojiyi etkin kullanamamak dersin sıkıcı olmasına ve verim elde edilmemesine sebep olmaktadır" şeklindedir. Öğretmenin öğrenciyi tanıması ve iyi bir iletişim bağı kurması sınıf yönetiminde önem arz eden hususlar içerisinde yer edinmektedir. Ö6 no'lu öğretmen bu hususu "Öğrencileri tanıma gereksiniminde bulunmadan derse girip çıkma, öğrencinin sevgisini kazanmaya çalışmadan sınıfa hakim olmak mümkün değildir" şeklinde dile getirmektedir. Her öğrencinin hazırbulunuşluk düzeyinin farklı olmasının öğretmenlerin sınıf yönetimini zorlaştıran hususlar içerisinde olduğu görülmüştür. Ö13 no'lu öğretmenin bu soruna yönelik görüşü "Her öğrencinin zeka düzeyi ve anlama kapasitesi farklıdır. Öğretmen hangi düzeyde anlatmalı ki hem bütün öğrencilerin anlamasını sağlamalı hem de zeka düzeyi yüksek olanların geride kalmayıp daha iyi bilgi almasını sağlamalı" şeklinde dile getirmiştir. Öğrenci ile iyi bir iletişim kurmanın yanında bu mesafeyi korumanın da önemli bir unsur olduğunu Ö59 no'lu öğretmen; "Öğretmenliğimin ilk yıllarında öğrencilerle çok fazla içli dışlı olduğum için onların saygısını kaybettiğim zamanlar oluyordu ve onları derse katmakta zorlanıyordum. Öğrencilerinle seviyeli bir samimiyet kurmak öğrencinin sana olan saygısını ve derse olan dikkatini de artırır" diyerek öğretmenliğin ilk dönemlerinde yaşadığı zorluklardan birini öğrencilerle düzeyli bir ilişki kuramamak olarak ifade etmiştir. Öğretmenin sınıf içerisinde ses tonunu etkili kullanması da sınıf yönetiminin önemli bir unsurudur. Ö9 no'lu öğretmen; "Ses tonumuz ne cılız ne de yüksek olmalı, konuşmamız net ve anlaşılır olmalıdır" diyerek öğretmenin sınıf yönetiminde yaşadığı sorunlardan birinin sesi etkili kullanmak olduğunu ifade etmektedir. Bu iletişimin karşılıklı olarak iyi tesis edilememesine yönelik Ö37 no'lu öğretmen görüşü "Öğretmenin öğrencileriyle olan iletişiminde yani, karşılıklı iletişimdeki aksaklık sınıf yönetimini zorlaştırmaktadır" şeklindedir. Farklı sosyal ve kültürel çevrelerden gelen 
öğrencilerin de sınıf yönetimini zorlaştırdığını Ö51 no'lu öğretmen şu şekilde ifade etmiştir: "Öğrencilerin kültürel farklııkları ve aile yapılarındaki aksaklıklar nedeniyle öğretmen çok büyük sıkıntılar yaşamaktadır" Ö12 no'lu öğretmen de bu durumda ne yapılması gerektiğini şu şekilde açıklar: "Tüm öğrencilerin zeka, psikolojik durum, ruh sağlığı ve ekonomik durumları birbirinden farklıdır. Burada bir dengenin sağlanıp tüm öğrencileri sahiplenen bir öğretmenlik anlayışı geliştirmek gerekir" demektedir. Kültürel farklılıklara sahip öğrencileri bir arada etkili bir şekilde yönetebilmek kuşkusuz önemli bir öğretmenlik yeterlik alanı olarak ifade edilebilir. Ö34 no'lu öğretmen ise "Dersle ilgisi olmayan haylaz öğrencilerin sürekli dersi sabote etmeleri bütün öğretmenleri zorlamaktadır" görüşüyle problemli öğrencilerin sınıf yönetimini zorlaştırdığına dikkat çekmektedir. Öğrenci hazırbulunuşluk seviyelerinin düşük olması, öğrencilerin derse hazırlıksız gelmeleri ve özel eğitim gerektirecek öğrencilerin sınıflara eşit dağıtılmamasından kaynaklı sınıf yönetimini zorlaştıran hususlar olarak şu öğretmen görüşleri verilmiştir: "Ö15:Sınıf yönetimi konusunda öğretmeni en çok zorlayan husus her öğrencinin algısının ve öğrenmeye hazırbulunuşluğunun birbirinden farklı olmasıdır", "Ö12:Derse hazırlıksız gelen bir öğretmenin disiplin sorunlarıyla karşılaşacağı unutulmamalıdır", "BEP li öğrenciler gibi sorunlu öğrencilerin sayısının sınıflara eşit dağılımının yapılmaması ögretmeni zorlayan bir husustur" ifadesi okul müdürlerinin özel eğitim ve ilgiye ihtiyaç duyan öğrencilerin sınıflara dengeli olarak dağıtılması konusunda hassas davranması ve öğretmenlerin de bu kapsamdaki öğrencilere yönelik eğitimsel yeterliklerini geliştirmenin önemli olduğunu ortaya koymaktadır. Öğrenci davranışlarına yönelik Ö61 no'lu öğretmen "Farklı kültürlere sahip ailelerin yetiştirdikleri çocuklarda haliyle farklı tutum ve davranışlar sergiliyor. Bunları idare edebilmek zorlayıcı olabiliyor" şeklindeki görüşüyle davranış kontrolüne, Ö54 no'lu öğretmen "Bazı öğrencilerin dersi ve öğretmeni umursamamaları ve saygısız davranışları nedeniyle oluşan sorunlar sınıf yönetimini zorlaştırıyor" şeklindeki görüşüyle saygısız öğrenci davranışlarına, Ö24 no'lu öğretmen "Sınıf yönetiminde beni en çok zorlayan konu olumsuz öğrenci davranışları oldu. Ahlaki eksiklikler öğrencilerin saygısız davranışları baş etmesi zor bir durum" şeklindeki görüşüyle ahlaki zafiyete, Ö25 no'lu öğretmen "Sınıfta ilgi çekmeye çalışan derste olmadık yere olmadık hatalar yapan öğrencinin sorununu çözmekte bazen zor olabilir" şeklindeki görüşüyle sınıf içerisinde dikkat çekmek isteyen öğrencilere, Özellikle istenmeyen öğrenci davranışları ile baş etmede öğretmenlerin zorlandıklarını söylemek mümkündür. Öğrencilerin sorumluluklarını yerine getirmemeleri ve belirlenen kurallara uymamaları da sınıf yönetimini zorlaştıran hususlar olarak görülmüştür. Ö14 no'lu öğretmen “Öğrencilerin ders çalışmadan gelmesi ve ders materyali getirmeden okula gelmesi de sıkıntılı bir konudur. Çözülmezse başarı ve sınıf yönetimi konusunda sorun yaşanacaktır" görüşüyle öğrencilerin sorumluluklarını yerine getirmediğine dikkat çekerken, Ö20 no'lu öğretmen "Sınıf yönetiminde en zorlanılan husus ders anlatırken veya konuşurken bir kısım öğrencinin öğretmeni dinlemeyip kendi aralarında konuşması ve başka bir işle uğraşmasıdır" şeklindeki görüşüyle de sınıf kuralların ihlal edilmesi hususuna dikkat çekmektedir. Fiziki şartlar ve sınıfların kalabalık olması da öğretmenin sınıf yönetiminde karşılaşı̆ı̆ı sorunların temelinde yatan hususlardan biri olarak ön plana çıkmaktadır. Ö32 no'lu öğretmen "Fiziki ortamın elverişsizliği yani sınıfın karanlık olması sınıfın soğuk olması, oturma düzeni vs. öğrencilerin dikkatini dağıtır ve sınıf yönetimini zorlaştırır" fiziki şartlara dikkat çekerken, Ö16 no'lu öğretmen ise "Sınıf mevcudunun fazla oluşu istenilen düzeyde sessizliğin sağlanamamasına ve bu nedenle öğretmenin sesini duyurabilmek ve çocukların dikkatini toplayabilmek için daha fazla enerji harcamasına sebep olur ki bu durum öğretmenin ders saatini de doğru kullanmasını geciktirecektir" diyerek sınıf mevcutlarına dikkat çekmektedir.

3.2 Öğretmenliğin İlk Dönemleri İle Kıyaslandığında Sınıf Yönetimi Becerilerinin Ne Düzeyde Geliştiğine iliş̧kin Görüşler

Öğretmenliğin ilk dönemleri ile kıyaslandığında sınıf yönetimi becerilerinin ne düzeyde geliştiğine ilişkin görüşler 1 tema ve bu temaya ilişkin 10 alt tema frekanslarıyla birlikte Tablo 3' de sunulmuştur.

Tablo 3.Öğretmenliğin ilk Dönemleri ille Kıyaslandığında Sınıf Yönetimi Becerilerinin Ne Düzeyde Geliştiğine ilişskin Görüşler

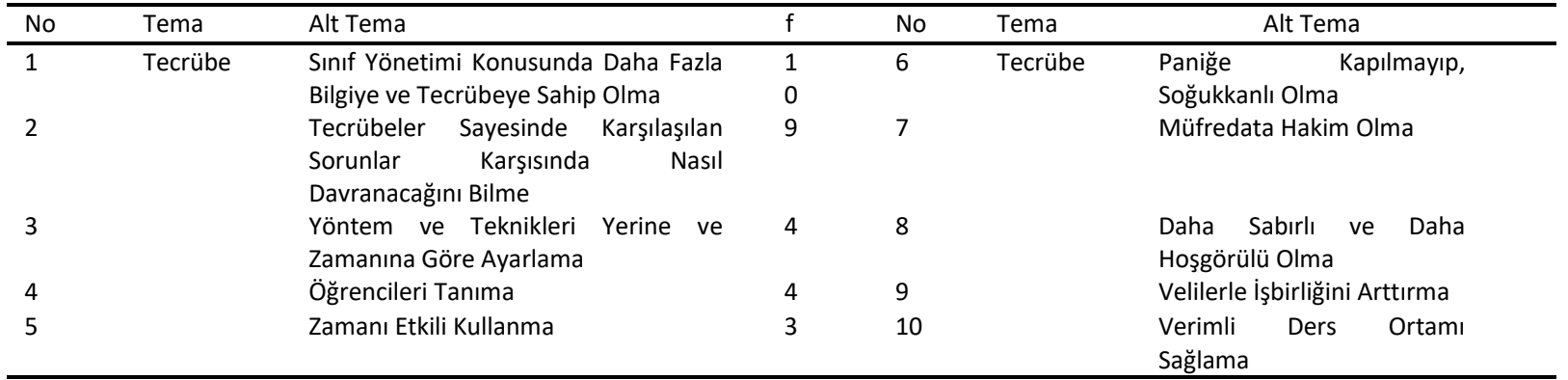


Tablo 3'te öğretmenlerin mesleklerinin ilk dönemleri ile kıyaslandığında sınıf yönetimi becerilerinin ne düzeyde geliştiğine dair görüşler "Tecrübe" teması adı altında, 20 alt tema ile birlikte sunulmuş olup, bu alt temalar; sınıf yönetimi konusunda daha fazla bilgiye ve tecrübeye sahip olma (f:10), tecrübe ile sayesinde karşılaşılan sorunlar ilişkin nasıl davranacağını bilme (f:9), yöntem ve teknikleri yerine ve zamanına göre ayarlama (f:4), öğrencileri tanıma (f:4), zamanı etkili kullanma (f:3), paniğe kapılmayıp soğukkanlı olmak (f:3), müfredata hakim olma (f:3), daha sabırlı ve daha hoşgörülü olma (f:2), velilerle işbirliğini arttırma (f:2), verimli ders ortamı sağlama (f:1) şeklinde gerçekleşmiştir.

Öğretmenlerin zamanla sınıf yönetiminde tecrübe kazandıklarına ilişkin görüşlerini Ö17 no'lu öğretmen "Mesleğimin ilk dönemlerine göre sınıf yönetiminde olumlu anlamda gelişme kaydettiğimi düşünüyorum. Bunda 13 yıllık mesleki tecrübenin etkisi var" şeklinde dile getirmiştir. Öğretmenlerin zamanla karşılaştıkları sorunlarla baş etme yollarında da tecrübe kazandıklarına ilişkin Ö40 no'lu öğretmen "ilk başlarda problemli öğrencilere karşı gösterdiğim tavırlarda büyük değişiklikler yaşadım. Önceleri tavırlarım çok farklı ve olumsuzdu. Çünkü acemilik vardı. Ama şimdi olgunlukla daha bir bilinçle problemli öğrencilerin durumlarına müdahale edebiliyorum" şeklinde görüşünü ifade ederek tecrübenin davranış değişikliğini pozitif yönde etkilediğini ifade etmiştir. Öğretmenlerin süreç içerisinde tecrübe kazandıkları diğer bir önemli husus ders sırasında kullanılan öğretim yöntem-teknikleri ve zamanı etkili kullanmadır. Ö50 no'lu öğretmen görüşü “Çocuğu, herhangi bir bilgiyi almaya hazır bir birey olarak görmeye başladım. Ancak bunun nasıl, ne zaman hangi yöntem ve teknikle yapılması gerektiğini bilmiyordum. Zaman içerisinde bu konuda kendimi geliştirdim" şeklinde öğretim yöntem-teknikleri konusuna vurgu yapmıştır. Ö46 no'lu öğretmen ise "ilk zamanlarda zaman konusunda sorun yaşıyordum. Artık zamanı daha etkili ve verimli kullanıyorum" diyerek zamanın etkili kullanılmasına vurgu yapmaktadır. Öğretmenlerin yaşanan sorunlar karşısında soğukkanlı davranabilmelerinin yanı sıra bu sorunlara yönelik daha sabırlı ve hoşgörülü davrandıklarına ilişkin Ö42 no'lu öğretmen "Muhatap olduğum yaş kitlesini zamanla daha iyi tanımam sabırla ve sakinliğimi koruyarak yaklaşmam gerektiğini görmem çok yol kat etmeme neden oldu." şeklinde görüş bildirmiştir. Çalışılan yaş grubunun bireysel ve toplu olarak iyi tanınması sınıf yönetimi becerilerine etki eden hususlardandır. Ö30 no'lu öğretmen "Öğrencilerin her biri birer çiçek ve her birinin farklı farklı ihtiyaçları var. Bu örneği göz önünde bulundurarak her öğrencinin ilgi, bilgi ve kabiliyeti, duygusu ve zekasına farklı yaklaşımlarda bulunarak hareket ettiğimi düşünüyorum” diyerek her öğrencinin ayrı özellik ve ihtiyaçları olduğunun tecrübesini elde ettiğine vurgu yapmıştır. Öğretmenlerin yıllar geçtikçe müfredata daha fazla hakim olmasında tecrübenin önemli katkı sağladığı görülmektedir. Bu durumun sınıf yönetimine olumlu yansımalarına yönelik olarak Ö44 no'lu öğretmen görüşü "ilk yıllarda gerek alan bilgisi gerekse bilgi aktarım noktasında yetersiz olduğum için sınıf yönetiminde ciddi sıkıntılar yaşadım” şeklinde ifade edilmiştir. Bu görüşlerden yola çıkarak, deneyime dayalı olarak alana hakimiyet ve öğretime ilişkin yeterlik düzeyinin geliştiğini ifade etmek mümkündür. Velilerle iyi ilişkiler kurmak doğrudan olmasa da dolaylı bir şekilde sınıf yönetimini etkiler. Ö47 no'lu öğretmen "yıllar geçtikçe velilerle olan ilişkilerim iyileştikçe velilerin bana karşı besledikleri iyi niyet çocuklara da yansıdı ve bu benim sınıfı daha kolay yönetmeme yardımcı oldu" şeklinde görüş bildirmiştir. Öğretmenlerin öğrencilerini tanıması için ev ziyaretlerinde bulunması, okulda velilerle bir araya gelerek söz konusu iletişim ve işbirliğine öğrencilerin şahit olmalarının sınıf içi öğrenci davranışları ve başarılarını olumlu şekilde etkileyeceğini söylemek mümkündür. Tüm bu hususların gelişmesinin olumlu bir sınıf ikliminin oluşmasında rol oynadığını Ö49 no'lu öğretmen görüşünden anlamak mümkündür: "Süreç içerisinde öğrenci psikolojisini daha iyi öğrenerek zamanı daha etkili kullanıp, öğrencilerin ihtiyaçları doğrultusunda verimli bir ders ortamı gerçekleştirebildim" şeklinde durumu özetleyen öğretmen de yukarıda sıralanan görüşlerde olduğu gibi sınıf yönetiminde yeterliliğe katkı sağlayan temel hususların, tecrübe, öğrencileri iyi tanıma, alana ve öğretime ilişkin gelişim ve aile ile etkili bir iletişim ve işbirliği olduğunu ifade etmişlerdir.

\subsection{Sınıf Yönetiminde Daha Önce Yapılan ve Hata Olarak Değerlendirilen; Deneyim Kazandıkça Farklı Tutum ve Davranış Geliştirilen Hususlara İlişkin Görüşler}

Meslek hayatında sınıf yönetiminde daha önce yapılan ve hata olarak değerlendirilen; deneyim kazandıkça farklı tutum ve davranış geliştirilen hususlara ilişkin görüşler 2 tema ve bu temalara ilişkin 26 alt tema/görüş frekanslarıyla birlikte Tablo 4' te sunulmuştur. 
Tablo 4. Sınıf Yönetiminde Daha Önce Yapılan ve Hata Olarak Değerlendirilen; Deneyim Kazandıkça Farklı Tutum ve Davranış Geliştirilen Hususlara İlişkin Görüşler

\begin{tabular}{|c|c|c|c|c|c|c|c|}
\hline No & Tema & Alt Tema & $f$ & $\begin{array}{l}\mathrm{N} \\
\mathrm{O}\end{array}$ & Tema & Alt Tema & $f$ \\
\hline 1 & $\begin{array}{l}\text { Ders } \\
\text { Boyutu }\end{array}$ & $\begin{array}{l}\text { Derse Hazırlıksız Olarak } \\
\text { Gelme }\end{array}$ & 3 & 1 & $\begin{array}{l}\text { Davranı } \\
\text { ş }\end{array}$ & $\begin{array}{l}\text { Derste Çok Sert Davranışlar } \\
\text { Sergileme (Katı Kurallar) }\end{array}$ & 10 \\
\hline 2 & & $\begin{array}{l}\text { Ders Süresinin Tamamını } \\
\text { Derse Ayırma }\end{array}$ & 3 & 2 & Boyutu & $\begin{array}{l}\text { Samimiyet ve Ciddiyet } \\
\text { Dengesini Kuramama }\end{array}$ & 6 \\
\hline 3 & & $\begin{array}{l}\text { Öğrenimin } \\
\text { Gerçekleşmesinde Çok } \\
\text { Sabırsız Olma }\end{array}$ & 3 & 3 & & $\begin{array}{l}\text { Güler Yüzlü Davranışlar } \\
\text { Sergileme }\end{array}$ & 5 \\
\hline 4 & & $\begin{array}{l}\text { Dersi Tek Düze İşleme } \\
\text { (Aynı Yöntem-Teknik) }\end{array}$ & 3 & 4 & & Otorite Kurma & 5 \\
\hline 5 & & $\begin{array}{l}\text { Dersi Öğretmen Merkezli } \\
\text { Işleme }\end{array}$ & 3 & 5 & & $\begin{array}{l}\text { Öğrencilere Ön Yargılı } \\
\text { Davranma }\end{array}$ & 5 \\
\hline 6 & & $\begin{array}{l}\text { Yüksek Ses Tonuyla Ders } \\
\text { Anlatma }\end{array}$ & 3 & 6 & & $\begin{array}{l}\text { Öğrenciler Üzerinde Korku } \\
\text { Oluşturmak. }\end{array}$ & 4 \\
\hline 7 & & Zamanı İyi Kullanamama & 2 & 7 & & $\begin{array}{l}\text { Öğrenciler Arası Ayrımcılık } \\
\text { Yapma }\end{array}$ & 2 \\
\hline 8 & & $\begin{array}{l}\text { Görsel ve İşitsel Duyuya } \\
\text { Hitap Etmeme }\end{array}$ & 1 & 8 & & $\begin{array}{l}\text { Öğrenci ile Empati } \\
\text { Kuramama }\end{array}$ & 2 \\
\hline 9 & & Başarı Grupları Oluşturma & 1 & 9 & & $\begin{array}{l}\text { Öğrenci Oturma Düzenini } \\
\text { Umursamama }\end{array}$ & 2 \\
\hline 10 & & $\begin{array}{l}\text { Ders Sırasında Çok Hızlı } \\
\text { Konuşma }\end{array}$ & 1 & 10 & & $\begin{array}{l}\text { Sorunsuz ve Sessiz Bir Sınıf } \\
\text { Beklentisi }\end{array}$ & 2 \\
\hline 11 & & $\begin{array}{l}\text { Sürece Sadece İyi Olan } \\
\text { Öğrencileri Katma }\end{array}$ & 1 & 11 & & $\begin{array}{l}\text { Başka Bir Meslektaşı } \\
\text { Kötüleme }\end{array}$ & 1 \\
\hline 12 & & Şive Ile Konuşma & 1 & 12 & & Not İle Tehdit Etme & 1 \\
\hline 13 & & Yazılı Sorularını Zor Sorma & 1 & 13 & & Tutarlı Olmama & 1 \\
\hline
\end{tabular}

Tablo 4'te meslek hayatında daha önce yapılıp hata olarak değerlendirilen; deneyim kazandıkça farklı tutum ve davranış geliştirilen hususlar "Ders Boyutu" ve "Davranış Boyutu" temaları ve bu iki temaya ait 26 alt tema birlikte verilmiştir. "Ders Boyutu" alt temaları; derse hazırlıksız olarak gelme (f:3), ders süresinin tamamını derse ayırma (f:3), öğrenimin gerçekleşmesinde çok sabırsız olma (f:3), dersi tek düze işleme (farklı yöntem-teknik) (f:3), dersi öğretmen merkezli işleme (f:3), yüksek ses tonuyla ders anlatma (f:3), zamanı iyi kullanamama (f:2), görsel ve işitsel duyuya hitap etmeme (f:1), başarı grupları oluşturma (f:1), ders sırasında çok hızlı konuşma (f:1), sürece sadece iyi olan öğrencileri katma (f:1), şive ile konuşma (f:1), yazılı sorularını zor sorma (f:1). "Davranış Boyutu" alt temaları; derste çok sert davranışlar sergileme (katı kurallar) (f:10), samimiyet ve ciddiyet dengesini kuramama (f:6), güler yüzlü davranışlar sergileme (f:5), otorite kurma (f:5), öğrencilere ön yargılı davranma (f:5), öğrenciler üzerinde korku algısı oluşturmak (f:4), öğrenciler arası ayrımclık yapma (f:2), öğrenci ile empati kuramama (f:2), öğrenci oturma düzenini umursamama (f:2), sorunsuz ve sessiz bir sınıf beklentisi (f:2), başka bir meslektaşı kötüleme (f:1), not ile tehdit etme $(f: 1)$, tutarlı olmama $(f: 1)$.

Ders öncesi iyi bir planlama hem derse hazırlıklı gelinmesine (etkinlik bağlamında) hem de ders süresinin iyi kullanılmasını sağlayarak sınıf yönetimine katkı sağladığını Ö16 no'lu öğretmen görüşünde "Ders planını yapmadan ve zamanı hesaplamadan gittiğimde yetiştirmek ve düzeni sağlamakta zorluk çekiyordum. Ama zamanla bunu da anladım ve hazırlık ve plan yaparak daha düzenli hale getirdim" ve Ö11 no'lu öğretmen görüşü ise "Derste konuyu işledim ama zamanı iyi ayarlamadığımdan dolayı öğrencilere ödev veremeden zil çaldı. Öğrencilerde beni dinlemeden dışarı çıktı. O gün otoriteyi iyi sağlayamadığımı ve zamanı iyi kullanamadığımı anladım" şeklindedir. Ders süresinin tamamının ders için ayrılması da hata olarak görülen hususlar içerisinde yer alırken Ö36 no'lu öğretmen bu durumu, "Sürekli ders ve konu odaklı olmaya çalışıyordum. Müfredatı yetiştirmeme korkusu aşırı disipline sebep oluyordu. Ama derste sadece ders işlemeyip farklı etkinlikler yapmak gerekiyor" şeklinde görüş bildirerek ders içerisinde farklı etkinlikler gerçekleştirilmesi üzerinde durmaktadır. Mesleğin ilk yıllarında sınıf yönetiminde hata olarak görülen hususların öğretmenin dersi işleyiş şekliyle yakından ilgili olduğu görülmüştür. Ö18 no'lu öğretmen "Öğretme ve öğrenme gerçekleştirilirken farklı öğretim teknolojilerinden faydalanmalı, farklı materyaller kullanarak öğrencilerin 
birden fazla duyusuna hitap ederek, dersi etkili hale getirmelidir" görüşüyle dersin farklı yöntem-teknik ile işlenmesine, Ö32 no'lu öğretmen "Dersi sürekli teorik olarak işliyordum. Öğrencilerin yüzüne bakmadan tahtaya yoğunlaşıyordum. Bunun öğrencileri sıktığını ve verimsiz olduğunu fark ettim. Dersleri uygulamalı bir şekilde anlatmaya çalıştım" dersin öğrenci merkezli işlenmesine, Ö29 no'lu öğretmen "Dersi tek duyudan ziyade birden fazla duyuya hitap ederek işlemek dersin kalıcılığını, verimini arttırılmasını sağladığını gördüm” diyerek dersin birden fazla duyuya hitap edecek şekilde işlenmesine vurgu yapmıştır. Görüşlerin genel olarak planlı, hazırlığa dayalı, öğrenci merkezli ve etkinlik temelli olarak işlenmesine dair öğretmenliğin ilk dönemlerinde sorunlar yaşandığı ancak; edinilen tecrübe ile yapılan yanlışların farklına varılarak söz konusu hususlarda pozitif yönde bir tutum ve davranış değişikliğinin gerçekleştiğini söylemek mümkündür. Mesleğin ilk yıllarında öğretmenlerin sesi kullanma noktasında hata da yaptıklarına ilişkin bulgulara rastlanmıştır. Bu kapsamda Ö29 no'lu öğretmen "Ses tonunu hep aynı tutulmasından ziyade yani sürekli alçak sesle anlatmak yerine konunun akışına göre yükseltilmesi ders ve öğrenciler üzerinde etkili oluyor" diyerek, ses seviyesinin konunun akışına göre belirlenmesi gerektiğini, Ö21 no'lu öğretmen ise "Ders işleme sürecinde çok hızlı konuştuğumu, öğrencilere bu şekilde yeterince faydalı olamayacağımı fark ettim ve bunu zamanla yendim" diyerek hızı konuşmanın olumsuz etkilerini fark edip bunu düzelttiğini, Ö29 no'lu öğretmen de "Dilimi, konuşmamı, hitabımı bölgesel şivelerden arındırarak, diksiyonumu geliştirmem öğrenciler üzerinde, ders üzerinde oldukça yararlı oldu" diyerek konuşmasını düzelterek daha etkili bir şekilde iletişim kurduğunu ve ders işlediğini ifade etmiştir. Bu görüşler, öğretmenlerin zamanla sesi kullanma, etkili iletişim ile bilgiyi aktarma ve öğrenmenin niteliğini geliştirerek sınıf yönetimi yeterliklerini geliştirdiklerini göstermektedir. Öğretmenin sergilemiş olduğu davranışlar sınıf yönetiminde belirleyici rol oynamaktadır. Öğretmenlerin bu bağlamda mesleklerinin ilk yıllarında sergilemiş oldukları ve hata olarak değerlendirdikleri görüşleri Ö14 no'lu öğretmen "Öğrencilerle olan ikili ilişkilerimizde ya da sınıfta var olan toplu ilişkimizde ne çok fazla otoriter, ne de zorla dersi aktaran bir öğretmen olmak mesleği etkili bir şekilde icra etmemize katkı sağlar" diyerek katı kuralların işi zorlaştıran bir hataya dönüşebileceğinden, Ö14 no'lu öğretmen "Öğrenciye yeteri değeri verip, onların anlayacağı şekilde yaklaşmak otorite ve aradaki mesafeyi korumak gerekir" diyerek samimiyet dengesine, Ö34 no'lu öğretmen "Öğrencilerime çok güler yüzle yaklaştım ve samimi davrandım. Bunun suistimal edildiğini gördüm. Bu da beni sınıf yönetimi konusunda çok zorladı" diyerek sadece güler yüzlü, kuralsız ve fazla esnek olmanın yanında kural ve düzeni ile mesafeyi korumak gerektiğine, Ö16 no'lu öğretmen "Sınıf kurallarını net bir şekilde belirtmeden sınıfa girdiğim için tam bir hakimiyet ve otorite sağlayamıyordum. Bunu fark edip daha düzenli davranmaya başladım" diyerek sınıf kurallarının net bir şekilde ortaya konmamasından kaynaklı hatadan, Ö37 no'lu öğretmen "Daha önce öğrenciler hakkında ön yargılara kapılırdım. Zaman geçtikçe deneyim kazanarak bu konularda daha az hataya ve ön yargıya düşmekteyim" diyerek ön yargılı olmamaya, Ö15 no'lu öğretmen "Ben her ne kadar baskı ve korkuya dayalı öğrencilerime yaklaşmaya çalıştıysam onlar daha da arsız olmaya ve durumun kötüye giden bir süreç olduğunu anladım. Yanlış yaptığımı fark ettim sonra öğrencilerimi sevgiyle kucaklamaya başladım” diyerek öğrenciler üzerinde korku algısından uzak bir anlayış geliştirmek gerektiğine, Ö34 no'lu öğretmen "ilk öğretmenliğe başladığımda ders işlerken başarılı olan öğrencilere daha fazla söz hakkı verip onlarla dersi işlediğimi fark ettim” diyerek öğrenciler arasında bir ayrım gözetmemek gerektiğine, Ö12 no'lu öğretmen "Zamanla anladım ki empati kurup öğrenciyi anlamak ve bunu başarmak öğrencinin gözünü korkutmaktan, bağırıp çağırmaktan daha etkili sonuçlar veriyor" diyerek öğrenciler ile empati kurulması gerektiğine, Ö16 no'lu öğretmen ise "illk önceleri oturma düzenini umursamıyordum. Samimi olan arkadaşlar yan yana oturunca zapt edemiyordum. Sonradan oturma planını önemseyince sınıf daha düzenli hale geldi" diyerek oturma düzeninin sınıf yönetimine etkisine, Ö64 no'lu öğretmen "Sınıfta sürekli sessizlik, disiplin isteyen bir tavrım vardı. Bunun hata olduğunu zamanla anladım. Çocuğun derste konuşmaya, gülmeye, ara vermeye, dinlenmeye ihtiyacı vardır" diyerek sessiz bir sınıf beklentisi isteğinden, Ö23 no'lu öğretmen "Bir meslektaşınızı kötülemek bir hataydı. Benden önceki öğretmenin yaptığı bir uygulamayı çok saçma bulduğumu söylemiştim. Bir meslektaşınız ne yaparsa yapsın öğrencilere öğretmenlerin yaptığı her şeyin bir sebebi olduğunu söylemek en iyisidir" diyerek diğer öğretmenler hakkında olumsuz fikirlerini öğrencilerle paylaşmanın yanlışlığından, Ö62 no'lu öğretmen ise "Not ile tehdit etmek çok büyük bir hata. Dersle ilgisi olmayan bir öğrenciye not tehdidi bir işe yaramaz" diyerek not ile tehdit etmenin her öğrenci için anlam ifade etmediğini ifade etmediğini, Ö59 no'lu öğretmen "Öğretmenliğimin ilk yıllarında tutarsız davranışlarımın öğrencileri kötü yönde etkilediğini gördükten sonra daha tutarlı tepkiler vermeye özen gösterdim" diyerek tutarlı olmaya, vurgu yapmıştır. Öğretmenlerin sınıf yönetimindeki davranışlarına ilişkin bu görüşler değerlendirildiğinde, öğretmenlerin mesleklerinin ilk dönemlerinde sınıfta sert, katkı bir öğretmen davranışı veya oldukça gevşek bir tutuma sahip oldukları, sınıf kurallarını usule uygun şekilde belirlemedikleri ancak, zamanla yaptıkları hataların farkına vararak davranışlarını daha pedagojik ve etkili sınıf yönetimi çerçevesinde düzenlediklerini ifade etmişlerdir. Bu görüşler bir bütün olarak değerlendirildiğinde öğretmenlerin mesleğin ilk dönemlerinde bir çok hatalı davranış sergiledikleri ve olumsuz tutuma sahip olduklarını söylemek mümkündür. Bu hataları zamanla, tecrübeye dayalı olarak düzelttikleri

(Kastamonu Eğitim Dergisi, 28(1), 2020) 
ve sınıf yönetimi yeterliklerini zamanla geliştirdikleri görülmektedir. Bu durumun mesleği ilk yıllarında eğitimsel açıdan bir çok soruna yol açtığı ve eğitim kalitesine olumsuz yansımalarda bulunduğunu söylemek mümkündür.

\section{Mesleğe Yeni Başlayan Bir Öğretmenler için, Sınıf Yönetimine i̇lişkin Tavsiyeler}

Öğretmenlerin mesleğe yeni başlayan bir öğretmene, sınıf yönetimine ilişkin tavsiyeleri 4 tema ve bu temalara ilişkin 36 alt tema/ görüş frekansları ile birlikte Tablo 5'te sunulmuştur.

\begin{tabular}{|c|c|c|c|c|c|c|c|}
\hline No & Tema & Alt Tema & $f$ & No & Tema & Alt Tema & $f$ \\
\hline 1 & Öğretmen & Samimiyet & 17 & 1 & Sınıf İklimi & Kuralların Belirlenmesi & 17 \\
\hline 2 & Özellikleri & Planlama & 11 & 2 & & Iffade Özgürlüğü & 16 \\
\hline 3 & & Öğrenciye İsmi ile Hitap & 10 & 3 & & Öğrenci Motivasyonu & 10 \\
\hline 4 & & Ses Tonu & 9 & 4 & & Bireysel Farklılıkların Tespiti & 10 \\
\hline 5 & & Sabır ve İstikrar & 9 & 5 & & Derse Katılım & 4 \\
\hline 6 & & Tutarlılık & 8 & 6 & & Sınıfta Coşku ve Sinerji & 3 \\
\hline 7 & & Disiplin ve Ciddiyet & 8 & 7 & & $\begin{array}{l}\text { Öğrencilere } \\
\text { Uygulamalar }\end{array}$ & 3 \\
\hline 8 & & Vücut Dili & 6 & 8 & & Öğrencilere Yönelik Empati & 2 \\
\hline 9 & & Sözel ve Fiziksel Şiddet & 6 & 9 & & $\begin{array}{l}\text { İstenmeyen Davranışlara Karşı } \\
\text { Tedbir }\end{array}$ & 2 \\
\hline 10 & & Ailelerle İletişim & 6 & 10 & & Demokratik Ortam & 2 \\
\hline 11 & & Alan Hakimiyeti & 5 & 11 & & Öğrenci Devamlılığı & 1 \\
\hline 12 & & İş Memnuniyeti & 5 & 1 & Yöntem- & Etkili Yöntem ve Teknik & 11 \\
\hline 13 & & $\begin{array}{l}\text { Öğrencilere } \\
\text { Duyarlılık }\end{array}$ & 4 & 2 & Teknik & Zamanın Etkili Kullanımı & 9 \\
\hline 14 & & $\begin{array}{l}\text { Kılık kıyafeti- Hal ve } \\
\text { hareket- Davranış }\end{array}$ & 3 & 3 & & Görsel ve İşitsel Etkinlikler & 5 \\
\hline 15 & & $\begin{array}{l}\text { Tecrübesizliğin } \\
\text { hissettirilmemesi. }\end{array}$ & 3 & 4 & & Dersi Oyunlaştırma & 3 \\
\hline 16 & & Derse zamanında girme & 1 & 5 & & Pekiştirec & 2 \\
\hline 17 & & Öğrenci ile tartışmama & 1 & 6 & & Değerlendirme Sistemi & 2 \\
\hline 1 & Mekan & Mekanın Fiziksel Şartları & 2 & 7 & & $\begin{array}{l}\text { Soyut } \\
\text { somutlaştırılma }\end{array} \quad$ kavramların & 2 \\
\hline 2 & & Sınıf Oturma Düzeni & 1 & 8 & & Teknoloji Kullanımı & 2 \\
\hline
\end{tabular}

Tablo 5' te meslekte tecrübe kazanmış öğretmenlerin, mesleğe yeni başlayan öğretmenlere sınıf yönetimine ilişkin tavsiyeleri 4 tema (Öğretmen Özellikleri- Mekan- Sınıf íklimi- Yöntem-teknik) ve bu temalara ait 38 alt tema ile birlikte verilmiştir. "Öğretmen Özellikleri” temasına ait alt temalar; samimiyet (f:17), planlama (f:11), öğrenciye ismi ile hitap (f:10), ses tonu (f:9), sabır ve istikrar (f:9), tutarlılık (f:8), disiplin ve ciddiyet (f:8), vücut dili (f:6), sözel ve fiziksel şiddet (f:6), ailelerle iletişim (f:6), alan hakimiyeti (f:5), iş memnuniyeti (f:5), öğrencilere karşı duyarlılık (f:4), kılık-kıyafet ( $f: 3)$, tecrübesizliğin hissettirilmemesi ( $f: 3)$, derse zamanında girme (f:1),öğrenci ile tartışma (f:1). "Mekan" temasına ait alt temalar; mekanın fiziksel şartları (f:2), sınıf oturma düzeni (f:1). "Sınıf iklimi" temasına ait alt temalar; kuralların belirlenmesi (f:17), ifade özgürlüğü (f:16), öğrenci motivasyonu (f:10), bireysel farklılıkların tespiti ( $f: 10)$, derse katıım (f:4), sınıfta coşku ve sinerji (f:3), eşit uygulamalar ( $f: 3)$, öğrencilere karşı empati ( $f: 2$ ), istenmeyen davranışlara karşı tedbir (f:2), demokratik ortam (f:2), öğrenci devamlılığı (f:1). "Yöntem-Teknik" temasına ait alt temalar; etkili yöntem-teknik (f:11), zamanı etkili kullanma (f:9), görsel ve işitsel etkinlikler (f:5), dersi oyunlaştırma (f:3), pekiştireç (f:2), değerlendirme sistemi (f:2), soyut kavramları somutlaştırma (f:2) ve teknoloji kullanımıdır (f:2).

Tabloda görüldüğü gibi, mesleğe yeni başlayan bir öğretmenin "Öğretmen Özellikleri” temasına ilişkin tavsiyeleri ağırlık kazanmaktadır. Bir başka deyişle öğretmen görüşleri ağılıklı olarak öğretmen tutum ve davranışları ile niteliklerine yönelik olmuştur. Bu kapsamda görüş ifade eden öğretmenlerden 58 no'lu öğretmen "Dersin iyi bir şekilde işlenmesi öğretmenin kendisini öğrencilere sevdirmesi açısından çok önemlidir. Öğrenci öğretmeni severse derse katılımı daha verimli olur" diyerek öğrencilerle mesafeli bir samimiyete, Ö10 no'lu öğretmen "Hazırlığını tam yapan konuya hakim olan bir ögretmenin sınıfa da hakim olması kolaylaşır" diyerek planlamaya, Ö19 no'lu öğretmen "Öğrencilerin hepsinin kendisini tanıtmasına izin verin. Ders bitiminde hepsinin ismini öğrenmeye çalışın. Bu diyalog kurmada kolaylık 
sağlayacaktır" diyerek öğrenci isimlerinin öğrenilmesine, Ö28 no'lu öğretmen "Ses tonu, jest ve mimiklerle ders hareketli hale getirilmeli" diyerek sesin nasıl kullanılması gerektiğine, Ö58 no'lu öğretmen "Öğretmenliğin temel kuralı sabırlı ve sakin olmaktır. Siz ne oranda kontrolünüzü kaybederseniz işlerin istenmeyen yerlere gitme olasılığı o kadar artar" diyerek sabır ve istikrara, Ö3 no'lu öğretmen "Öğretmenin söz ve davranışı birbiriyle tutarlı olmalıdır. Sınıfta sigara içmek yasak deyip, öğretmenin bahçede öğrenci gözü önünde sigara içmesi tutarlı bir davranış olmaz" diyerek tutarlılığa, Ö8 no'lu öğretmen "Ne sürekli asık suratı olmalı ne de sürekli güler yüzlü olmalıdır. Çocuklarla birlikte gülmeli fakat derse dönmesini ve ağırlığını koymasını bilmelidir" diyerek disiplin ve ciddiyete, Ö14 no'lu öğretmen "Vücut dilini iyi kullanmak öğretmeni öğrencilerine yaklaştırır, öğretmeni daha iyi tanımalarını sağlar" diyerek vücut dilinin kullanılmasına, Ö3 no'lu öğretmen "Öğretmenin öğrenciyle iletişimi çok önemlidir. Öğretmen sözel ve fiziksel şiddetten kaçınmalıdır" diyerek sözel ve fiziksel şiddete, Ö34 no'lu öğretmen "Öğrencinin ailesiyle tanışmalı, sosyal ve kültürel yaşamını öğrenmeli ve ekonomik durumunu bilmelidir. Öğrencileri tanıyınca onların sergiledikleri davranışları ve nedenlerini daha kolay bir şekilde öğrenmesine yardımcı olur" diyerek aile ile iletişimine, Ö22 no'lu öğretmen "Öğretmenin öncelikle alanına hakim olması gerekir. Alanına hakim olmayan öğretmen şiddete başvurur. Bu da çocukların özgüvenini yitirmesine neden olur" diyerek alan hakimiyetine, Ö52 no'lu öğretmen "Öğretmenin mesleğini severek isteyerek yapması çok önemli. Çünkü yeni bir neslin geleceği öğretmenle şekillenmeye başlayacaktır. Ancak bu şekilde verim alınabilir" diyerek öğretmenin iş memnuniyetine, Ö28 no'lu öğretmen "Öğrenci önemsendiğini gördüğü zaman daha başarılı olacaktır ve derse dört elle sarılacaktır" diyerek öğrencilere karşı duyarlılığa, Ö55 no'lu öğretmen "Öğretmen öğrencinin gözünde bir model oluşturduğu için öğretmen kılık kıyafetine ve hareketlerine dikkat etmelidir" diyerek kılık-kıyafete, Ö39 no'lu öğretmen "Mesleğe yeni başlayan öğretmen acemiliğini hissettirmemelidir. Mesleğine hakim olduğunu hissettirerek otorite kurabilmelidir" diyerek tecrübesizliğin hissettirilmemesine, Ö23 no'lu öğretmen "Derse zamanında girmek çocukların öğretmenin disiplinli biri olduğunu anlamasını sağlar" diyerek derse zamanında girilmesine, Ö59 no'lu öğretmen "Hata yapan öğrencilerle sınıfın önünde tartışmayın. Alevlenebilecek bir tartışma doğuyorsa, öğrencilerle karşı karşıya gelmeyin. Böyle bir durumda öğrenci ile dışarı çıkıp konuşun" diyerek öğrencilerle tartışmamaya, dikkat çekmektedir. "Mekan" temasına ilişkin tavsiyeler incelendiğinde; Ö1 no'lu öğretmen "Öğretmen sınıf oturma düzenini sınıf iklimine göre oluşturmalıdır. Öncelikle öğrencileri tanımalı sonra düzeni oluşturmalıdır" diyerek sınıf düzenine yönelik, Ö29 no'lu öğretmen "Fiziksel şart eğitimin verilmesini çok zorlaştıran etkenlerdendir. Bunları iyileştirmek verimin artmasını sağlayacaktır" diyerek sınıf ortamına yönelik tavsiyelerde bulunmuştur. "Sınıf İklimi" temasına ilişkin ise; Ö23 no'lu öğretmen "Çocuklarla beraber sınıfın kuralları, dersin işlenme şekline belirtilmeli bu sayede çocuklar başkasının koyduğu kurallar yerine kendi kurallarına uyarken daha dikkatli olur" diyerek kuralların öğrencilerle oluşturulmasına, Ö19 no'lu öğretmen "Her çocuk özeldir, biriciktir. Öğrencilere seviyelerine uygun hitap edilmelidir. Sade bir dil kullanmalıyız. Her öğrenciye söz hakkı verilmelidir" diyerek her öğrencinin değerli olduğunu ve düşüncelerini ifade etmelerine fırsat tanımak gerektiğine, Ö58 no'lu öğretmen "Öğrencilerin hazır oluş ve beklentilerini göz önünde bulundurmalısın. Bu durumda öğrencilerin sıkılmalarını engellemiş ve motivasyonlarını sağlamış olursun” diyerek öğrenci motivasyonuna, Ö52 no'lu öğretmen "Öğretmen öğrencinin yaş grubunun fiziksel, sosyal ve psikolojik yönünü her zaman göz önünde bulundurmalı ona göre davranmalıdır" diyerek bireysel farklılıkların belirlenmesine, Ö16 no'lu öğretmen "Öğrencilerin bireysel farklılıklarını göz önünde bulundurmalı, yeteneklerinin geliştirilmesine yardımcı olmalıdır. Öğrencinin derse etkin katılımını sağlamalıdır” diyerek öğrencilerin bireysel farklılıklarına göre derse katılımlarının sağlanmasına, Ö2 no'lu öğretmen "Öğrencilerin sıkıldığını fark ediyorsunuz ve bir şeyler yapmanız gerektiğini hissediyorsunuz. Onların dikkatini toplayacak kısa hikayeler anlatabilir ve espriler yapabilirsiniz" diyerek sınıfta coşku ve sinerjinin oluşturulmasına, Ö38 no'lu öğretmen "Öğrenciler arasında kesinlikle ayrım yapmamalı ve etik davranılmalıdır. Her birey eşittir ve her bireye eşit söz hakkı tanınmalıdır" diyerek öğrencilere yönelik uygulamalarda eşitliğe, Ö15 no'lu öğretmen "Öğretmenlere derste öğrencilerini sabırla dinlemelerini öneriyorum. Empati kurmalarını öneriyorum, farklı davranış gösteren öğrencilerin bu davranışı sergileme nedenini araştırması, öğrencisini anlayıp ona göre tutum belirlemesini sağlayacaktır" diyerek empati kurulmasına, Ö1 no'lu öğretmen "Öğretmenin istenmeyen davranışlara karşı bir B Planı olmalıdır" diyerek istenmeyen davranışlara karşı her zaman hazırlıklı olunması gerektiğine, Ö1 no'lu öğretmen "Demokratik bir ortamın sağlanmasına çalışılmalıdır" diyerek demokratik bir sınıf ortamının oluşturulmasına, Ö2 no'lu öğretmen “Öğrenci devamı sürekli takip edilmelidir. Devamsızlık durumlarında idare ve aile ile işbirliğine gidilmelidir" diyerek öğrenci devamlılı̆ına yönelik tavsiyelerde bulunmuşlardır. Öğretmenlerin "öğretim yöntem ve teknikleri” kapsamında değerlendirilebilecek tavsiyeleri incelendiğinde Ö28 no'lu öğretmen "Her öğrenciye hitap eden bir şeyler vardır, değişik teknik yöntemler kullanılmalı. Konu sadece sunuş yoluyla anlatılmamalı. Görsel ve işitsel zekaya da hitap etmelidir" diyerek dersin görsel ve işitsel duyulara hitap edecek farklı yöntem-tekniklerle işlenmesini, Ö25 no'lu öğretmen "Sınıf yönetiminde zaman da önemli kriterdir. Zamanın ders dışı ve ders ortamını bozucu etkilerine harcanması ve öğrencilerin sıkılmaması önemlidir" diyerek zamanın verimli kullanılmasını, Ö35 no'lu öğretmen “Materyal kullanacak. Sokaktan, evden, aileden örnekle 
pekiştirecek, konuyu böyle zengin hale getirecek. Yani görsel materyalin dışında örneklerle çekici hale getirecek" diyerek soyut kavramların somutlaştıııması ve materyal kullanımını, Ö58 no'lu öğretmen "Öğretmen dersi oyunlaştırarak süreci eğlenceli hale getirmelidir. Çocuğun derste konuşmaya, gülmeye, ara vermeye, dinlenmeye de ihtiyacı vardır" diyerek dersin bir oyun havasında işlenmesini, Ö54 no'lu öğretmen "Sınıf içerisinde istenen değil, istenmeyen davranışı öne çıkarmaktır. Sus bağırma, sus, kes, konuşma gibi ifadelerle öğretmen adeta bu davranışları pekiştirir. Böyle bir sınıf ikliminde sessizce dersini dinleyen öğrencinin pekiştirilmesi gerekirken adeta ödül, dersi sabote etmeye çalışan öğrenciye verilmektedir" diyerek ödül ve pekiştirecin davranış kazandırmada nasıl kullanılması gerektiğini, Ö58 no'lu öğretmen ise "Gelişen teknoloji ve değişen eğitim sistemine rahatça ayak uydurmak ve teknolojiyi sınıfta kullanmak eğitimin verimi ve kalıcılığı açısından çok önemlidir" diyerek teknolojinin sınıfta kullanılmasını tavsiye etmişlerdir.

\section{Sonuç ve Tartışma}

Eğitim etkinliklerinde, beklenen başarıyı elde etmenin birinci koşulu etkili bir sınıf yönetimi olarak görülmektedir (Aytekin, 2007). Sınıf yönetiminin etkililiği ise sınıf etkinliklerinin iyi organize edilmesi ve yönetilmesine bağlıdır (Ayaydın, 2010). Meslek yaşamına yeni başlayan öğretmenlerin sınıf yönetimi alanında yeterli deneyime sahip olmadıkları, sınıf ortamında karşılaştıkları olumsuzluklara ilişkin ne yapacaklarını tam olarak bilmedikleri (Alkan, 2007) gibi meslekte kıdem yılı fazla öğretmenlerinde yaklaşık üçte birinin sınıf yönetimi becerisi konusunda "orta" ve ortanın altında bir düzey sergiledikleri görülmüştür (Akın ve Koçak, 2007). Arslan'ın (2016) çalışmasında da öğrencilerin öğretmenlerini sınıf yönetimi ilkelerine genel olarak "orta" düzeyde uyduklarını tespit edilmiştir. Bu bulgular meslekte tecrübe kazanarak elde edilen sınıf yönetimi becerisinin de yeterli olmadığını ortaya koymaktadır.

Çalışmada öğretmenleri sınıf yönetiminde en çok zorlayan hususların ardında yatan nedenler incelendiğinde bunların öğretmen kaynaklı, öğrenci kaynaklı, mekan kaynaklı, veli kaynaklı, müfredat kaynaklı olduğu bulgulanmıştır. Öğretmen kaynaklı hususlarda en dikkat çeken alt temaların; öğretmenlerin alan yeterliği (alan bilgisi, yöntem-teknik kullanımı, teknolojiyi etkin kullanma, zamanı etkili kullanma), öğretmenin öğrenciye yönelik tutumu, davranışları (öğrenciyi iyi tanımamaktan kaynaklı hatalar, iletişimsizlik, öğrenci ile mesafeyi koruyamama) ve öğretmenin dış görünüşü (kılık-kıyafet) olduğu görülmektedir. Recepoğlu ve Ergün'ün (2017) çalışmalarında sınıf yönetimi becerilerine ilişkin en düşük ortalamaların "etkinlikleri öğrencilerin dikkat sürelerine uygun olacak şekilde planlayabilme, istenmeyen davranışları denetim altına almaktan çok, öğrencinin zamanını üretici etkinliklere yöneltebilme, sınıftaki grup dinamiğini etkili biçimde kullanabilme, ders sırasında istenmeyen davranışla karşılaştığında dersi bölmeden müdahale edebilme" maddelerinde görülmüş olup, bu sonuçların Özgan, Aydın ve Küllük (2011) tarafından yapılan araştırma bulgularıyla örtüştüğü görülmektedir. Çubukçu ve Girmen' in (2008) çalışmalarında öğretmenlerin alan hakimiyeti hususunda kendilerini yeterli, planlamada ise yetersiz gördükleri bulgulanmıştır. Öğretmeni sınıf yönetiminde zorlayan diğer bir husus da uygulanan müfredat olduğu görülmüştür. Şatoğlu'nun (2008) çalışmasında da sınıf yönetiminde sorunlara neden olan hususlardan birinin de öğrenciye öğretilmek istenen konuların öğrenci düzeyinin çok üstünde veya tam tersi çok altında olması, öğretilen konuların öğrenci dikkatini çekmemesi veya öğrenci ihtiyaçlarına yönelik olmaması olarak bulgulanmışır. Bu bulgular öğretmenlerin öğretim programını öğrencilerin düzeyine uygun şekilde tasarlayarak öğretimi etkili bir şekilde planlayamadıkları şeklinde yorumlanabilir. Bu durumda, öğrenme sürecine yeterince dahil edilememiş öğrencilerin sınıf yönetiminde istenmeyen davranışlara başvurma düzeyinin artacağından söz etmek mümkündür. Sınıf yönetiminde veli kaynaklı sorunların ise; sosyal ve kültürel farklılıktan ve veli tutumundan kaynaklı nedenler olduğu görülmüştür. Erdoğan, Kurşun, Şişman, Saltan, Gök ve Yıldız'ın (2010) çalışmalarında velilerin çoğunun kendi çocuklarının sınıf içi disiplinsiz davranışlar göstermediğini düşündüklerini bulgulanmıştır. Öğrenci kaynaklı nedenlerin ise; öğrencilerin akademik başarılarından ve öğrencilerin tutum ve davranışlarından kaynaklı olduğu görülmüştür. Dirlikli, Sakallı ve Akgün'ün (2015) çalışma sonuçlarında da sınıf yönetiminde öğrenci kaynaklı sorunların derse karşı ilgisizlik, derse hazırıksız gelme, ders çalışma alışkanlıklarının olmaması şeklinde bulgulanmıştır. Fiziki mekandan kaynaklı nedenler ise; sınıfın fiziki şartlarının yetersizliği ve sınıf mevcutlarının fazla olması gösterilmiştir. Dirlikli vd.(2015) çalışmalarında ortamdan kaynaklı olduğu düşünülen altyapı ve teknik donanım eksikliğinin sınıf yönetimini olumsuz etkilediği bulgulanmıştır. Aküzüm ve Özdemir Gültekin'in (2017) çalışma bulgularında sınıf mevcudu değişkenine göre 46 ve üzeri sınıf mevcudu olan öğretmenlerin sınıf yönetiminin iletişim becerileri noktasında daha az sınıf mevcutlu sınıf öğretmenlerine göre kendilerini daha düşük düzeyde yeterli görmüşlerdir.

Öğretmenliğin ilk dönemleri ile kıyaslandığında sınıf yönetimi becerilerinin ne düzeyde geliştiği ile ilgili görüşler incelendiğinde öğretmenlerin alan hakimiyeti, öğretim yöntem-tekniklerini kullanımı, zaman yönetimi, sınıf yönetimi 
becerileri, öğrencilere yönelik tutum ve davranışlar hususunda tecrübe kazandıkları görülmüştür. Rosas ve West'in (2009) çalışma bulgularında da aday öğretmenlerin sınıf yönetimi becerilerine ilişkin algılarının, öğretmenlere göre daha düşük olduğunu bulgulamışlardır. Bu sonuçların yanı sıra kıdem süresinin sınıf yönetimi becerilerini etkilediği çalışmalar da bulunmaktadır (Alkan, 2007; Erol, 2006; Korkut ve Babaoğlan, 2010; Özgün, 2008). Çalışma bulgularının aksine Yüksel (2013) ve Ritter ve Hancock (2007) çalışma sonuçlarında sınıf yönetimi becerilerine sahip olma düzeyleri ile mesleki kıdemleri arasında anlamlı bir fark görmemişlerdir. Alan yazın incelendiğinde ise kıdem arttıkça sınıf yönetimi bağlamındaki yeterliklerin geliştiğine ilişkin bulguların daha ağırlıkta olduğunu görmek mümkündür. Bu bulgular kıdemin sınıf yönetimi becerilerinde tek değişken olmasa da önemli bir belirleyici olduğu şeklinde yorumlanabilir. Sınıf yönetiminde daha önce yapılan ve hata olarak değerlendirilen; deneyim kazandıkça farklı tutum ve davranış geliştirilen hususların; öğretim becerileri boyutu ve davranış boyutunda gerçekleştiği görülmüştür. Öğretim becerileri boyutunda öğretmenlik mesleğinin ilk dönemlerinde hata olarak değerlendirilen hususların; farklı yöntem-teknik kullanmama, zamanın etkin kullanılmaması, ses tonunu ayarlayamama, ders öncesi planlama yapmama, öğretimin gerçekleşmesinde çok sabırsız olma, öğretmen merkezli ders işleme, farklı duyulara hitap edememe, öğrenci değerlendirme sürecini iyi uygulayamama, başarı grupları oluşturma şeklinde gerçekleştiği tespit edilmiştir. Özgan ve Yılmaz'ın (2009) çalışmalarında da müfettişlerin öğretmenleri sınıf yönetiminde öğretmeöğrenme süreci ve sınıf hakimiyeti konularında yeterli görmedikleri bulgulanmıştır. Bu bulgular, öğretmenlerin öğretim becerilerine ilişkin hizmet öncesi iyi yetişmedikleri ve tecrübeye dayalı olarak öğrendikleri şeklinde yorumlanabilir. Etkili bir sınıf yönetimi ile yakından ilişkili olan öğretim becerisine mesleğin ilk yıllarında öğretmenlerin yeterince sahip olmaması eğitim sürecinde önemli bir sorun olarak yakından incelenmeyi gerektirmektedir. Mesleğin ilk dönemlerinde sınıf yönetimine ilişkin davranış boyutunda yapılan hatalar ise; otorite kurma, öğrenci ile iletişim dengesini kuramama, not ile tehdit etme, çok sert veya katı kurallar, sınıf düzeni, öğrenci ile empati kuramama, öğrenciler üzerinde korku oluşturma, güler yüzlü davranışlar, sorunsuz ve sessiz bir sınıf beklentisi, öğrenci oturma düzenini umursamama, başka bir meslektaşı kötüleme noktasında gerçekleştiği görülmektedir. Doğan, Aydın ve Çalış’ ın (2000) araştırma bulgularında da sınıf yönetimine ilişkin 63 olumsuz davranış belirlenmiş olup, en fazla görülen olumsuz davranışların dayak atma, şiddet uygulama, vurdum duymaz tavır takınma, korkutma, bağırıp çağırma, azarlama, hakaret etme, kötü söz söyleme ve sert davranma olduğu görülmüştür.

Mesleğe yeni başlayan öğretmenlere yönelik tavsiyelerin dört temada gerçekleştiği görülmüş olup, bu dört tema, öğretmen özellikleri, mekan, sınıf iklimi, yöntem-tekniktir. Öğretmen özellikleri boyutunda öneriler; kılıkkıyafet, hal ve hareketlere özen gösterme, ses tonu- vücut dili kullanma, öğrenciye yönelik tutum ve davranışlar (samimiyet, sözel ve fiziksel şiddet kullanmama, öğrenci ile tartışmama, öğrenciye ismi ile hitap etme) alan hakimiyeti, söz ve davranışlarda tutarlılık, tecrübesizliğin hissettirilmemesi, sabır ve istikrar, ailelerle olumlu iletişim kurma, iş düzeni ve disiplini şeklindedir. Güçlü (2011) öğretmenlerin öğrencilere içten davranmaları, öğrencilerle empati kurulması, beden dilinin ustaca kullanılmasını, öğrencilerin derse katılımının artması ile sonuçlandığını ifade etmektedir. Can ve Arslan (2018) da yaptıkları çalışmada öğrencilerin öğretmenlerden bekledikleri davranışların daha esnek, anlayışlı, teşvik edici ve ödüllendirici, dersi etkinlik temelli işlemeleri ve iyi bir iletişime sahip olmaları şeklinde ifade etmişlerdir. Mekan temasında sınıf oturma düzeninin sağlanması ve sınıfın fiziksel şartlarının düzenlenmesi noktalarında öneriler sunulmuştur. Sınıf iklimi temasında yer alan öneriler; sınıfta coşku ve sinerjinin sağlanması, kuralların belirlendiği demokratik bir ortam içinde herkesin düşüncesini rahatça ifade edebileceği eşit uygulamalar, bireysel farklılıkların önemsendiği, derse devamlılık ve katılımın sağlandığı, istenmeyen davranışlara karşı tedbir alındığı, öğrencilere yönelik empati kurulması şeklindedir. Gerzon (1997) da demokratik bir sınıf ikliminin oluşturulması için öğretmenin de demokratik tutum ve davranışlara sahip olması gerektiğini vurgular. Öğretim yöntem ve tekniklerinin kullanılması temasına yönelik öneriler ise; farklı ve etkili yöntem ve tekniklerin kullanılması, teknolojiden yararlanma, zamanı etkili ve verimli kullanma, dersi bir oyun havası içerisinde işleme, pekiştireç kullanma, soyut kavramları somutlaştırarak verme ve uygun değerlendirme yöntem ve teknikleri kullanma şeklindedir. Erdoğan, vd.(2010) çalışmalarında öğrencilerin derse karşı ilgi ve motivasyonlarını arttırmak için öğretmenlerin farklı yöntem teknik kullanabilecekleri, derslerin gerçek hayatla ilişkilendirilebileceği, farklı konu ve örneklerle dersin zenginleştirilebileceği önerilmiştir. Dirlikli ve arkadaşlarının (2015) çalışmasının sonuçlarında etkili sınıf yönetimi için öğretmenlerin alan bilgisinin iyi olması ve teknolojiden yararlanması gerektiği, farklı ders işleme yöntem ve tekniklerini kullanabilmesini, konuşma ve beden dilini etkili kullanması gerektiği yönünde sonuçlara ulaşmışlardır. Çalışma bulgularının Milli Eğitim Bakanlığı’nın (2017) Öğretmen Yetiştirme ve Geliştirme Genel Müdürlüğü tarafından belirlenen “Öğretmenlik Mesleği Genel Yeterlilikleri” nin “Mesleki Bilgi” ve "Mesleki Beceri” yeterlilikleri ile de örtüştüğü görülmüştür.

Tüm bu bulgular ışığında öğretmenin etkili bir sınıf yönetimi gerçekleştirebilmesi için öğretmen; a)sınıf yönetimine etki eden tüm unsurlar (mekan, alan yeterliliği, öğrenci özellikleri, iletişim...v.b) hakkında farkındalık 
geliştirmeli, b)mesleki gelişime açık olmalı ve teknolojik gelişmeleri takip etmeli, c)öğrenci merkezli öğretim yöntem ve teknikleri kullanmalı, d)eğittiği yaş grubunun gelişimsel özelliklerini iyi bilmeli, e)çalıştığı çevreyi ve veli profilini iyi tanımalı, f)sınıf yönetimine ilişkin öğrencilerle yaşadığı sorunlarda veli, idare, rehberlik servisinden aktif olarak yararlanmalı, g)sınıf içinde çoşku ve sinerji oluşturacak bir ortam sağlamalı, h) mesleğe yeni başlayan öğretmenin derslere ilk altı aylık süreçte tecrübeli öğretmenle birlikte girmesi sağlanmalı (aday öğretmenlik programı), ı)davranışlarıyla bir rol model olmalıdır.

\section{Kaynakça}

Akın, U., Koçak, R. (2007). Öğretmenlerin sınıf yönetimi becerileri ile iş doyumları arasındaki ilişki. Kuram ve Uygulamada Ĕ̆itim Yönetimi, 51, 353-370

Aküzüm, C., Nazlı, K. (2017). Sınıf öğretmenlerinin sınıf yönetiminde karşılaştıkları disiplin sorunları, nedenleri ve bu sorunlarla baş etme yöntemlerinin değerlendirilmesi. International e-Journal of Educational Studies (IEJES), 1 (2), 88-102.

Aküzüm, C., Özdemir Gültekin, S. (2017). Sınıf öğretmenlerinin iletişim becerileri ile sınıf yönetimi becerileri arasındaki ilişkinin incelenmesi. Elektronik eğitim Bilimleri Dergisi,6, (12), 88-107

Alkan, H. B. (2007). ilköğretim öğretmenlerinin istenmeyen davranışlarla baş etme yöntemleri ve okulda şiddet. Yayımlanmamış yüksek lisans tezi, Niğde Üniversitesi Sosyal Bilimler Enstitüsü, Niğde.

Arslan, B. (2016). Öğretmenlerin sınıf yönetimi yeterliliklerine ilişkin öğrenci görüşleri. Yüksek Lisan Tezi. İstanbul Üniversitesi Sosyal Bilimler Enstitüsü.

Ayaydın, A. (2010). Görsel Sanatlar Eğitiminde Sınıf Yönetimi: Bir Nitel Araştırma Örneği. Uludağ Üniversitesi Eğitim Fakültesi Dergisi XXIII (1), 2010, 61-80

Aydın, M. (1998). Eğitim Yönetimi. Hatipoğlu Yayınevi, Ankara.

Aytekin, H. (2007). Sınıf Yönetimi ve Disiplinle ilgili Kurallar Geliştirme ve Uygulama. Leyla Küçükahmet (Ed.). Sınıf Yönetimi, Ankara: Nobel Yayıncılık.

Başar, H. (1999). Sınıf yönetimi. Ankara: Milli Eğitim.

Başar, H. (2008). Eğitim ve Sınıf Yönetimi Sınıf Yönetimi (Ed: Ağağlu, E.) Eskişehir: Anadolu Üniversitesi.

Büyüköztürk, Ş., Kılıç Çakmak, E., Akgün, Ö.E., Karadeniz, Ş. ve Demirel, F. (2009). Bilimsel Araştırma Yöntemleri (8.baskı). Ankara: Pegem Yayınları.

Can, E., Arslan, B. (2018). Öğretmenlerin Sınıf Yönetimi Yeterliklerine İlişkin Öğrenci Görüşleri. KSBD, C. 10, 18, 195-219

Celep, C. (2002). Sınıf yönetimi ve disiplin (Yenilenmiş 2. Baskı). Ankara: Anı Yayıncılık.

Creswell, J.W. (2007). Qualitative inquiry and research desing: Choosing among five approaches. (2nd Press). SAGE Publications.

Çubukçu, Z., Girmen, P. (2008). Öğretmenlerin sınıf yönetimi becerilerine ilişkin görüşleri. Bilig, 44, 123-142.

Demirtaş, H. (2006). Sınıf yönetiminin temelleri. H. Kıran (Ed.), Etkili sınıf yönetimi içinde (s. 1-34). Ankara: Anı.

Demirtaş, H. (2009). Sınıf yönetiminin temelleri. İçinde: H. Kıran (Ed.), Etkili sınıf yönetimi (5. Baskı), (ss. 1-34). Ankara: Anı Yayıncılık.

Dirlikli, M., Sakallı, A.F., Akgün, L. (2015). Matematik öğretmenlerinin sınıf yönetiminde karşılaştıkları sorunlar. Uluslararası Eğitim Bilimleri Dergisi, 5, 36-57.

Doğan, A. R., A. Aydın ve H. Çalış (2000). “Öğretmen Öğrenci iliş̧kilerinde Model Davranışlar.” Erzurum: XI. Ulusal Eğitim Bilimleri Kongresi, 27-30 Eylül, 2000, Eğitim Programları ve Öğretim, Bildiriler-I, 326-335.

Ergenekon, Y. (2004). İşe yeni başlayan zihinsel özürlüler öğretmenlerinin mesleksel sorunlarının belirlenmesi ve bu sorunları gidermeye yönelik çözüm önerilerin geliştirilmesi. Yayınlanmış Doktora Tezi, Anadolu Üniversitesi Eğitim Bilimleri Enstitüsü, Eskişehir.

Erdoğan, ì. (2011). Sınıf Yönetimi (14. Baskı). İstanbul: Alfa Yayınları

Erdoğan, M., Kurşun, E., Şişman, G., Saltan, F., Gök, A. \& Yıldız,I. (2010). Bilişim Teknolojileri Dersi Örneği Sınıf Yönetimi ve Sınıf İçi Disiplin Problemleri, Nedenleri ve Çözüm Önerileri Üzerine Nitel Bir Araştırma: EDAM, 10 (2), 853-891.

Erol, Z. (2006). Sınıf öğretmenlerinin sınıf yönetimi uygulamalarına ilişkin görüşleri. Yayımlanmamış yüksek lisans tezi, Afyon Kocatepe Üniversitesi Sosyal Bilimler Enstitüsü, Afyon. 
Erol, O., Özaydın, B., Koç, M. (2010).Sınıf Yönetiminde Karşılaşılan Olaylar, Öğretmen Tepkileri ve Öğrenciler Üzerindeki Etkileri: Unutulmayan Sınıf Anılarının Analizi.Kuram ve Uygulamada Eğitim Yönetimi,16, 25-47.

Evertson C. M., ve Weinstein, C. (2006). Classroom management as a field of inquiry. In C. M.Evertson \& C. Weinstein (Eds.), Handbook of Classroom Management: Research, practice, and contemporary issues (p. 3-15). Mahwah, NJ: Lawrence Erlbaum Associates, Inc.

Fidan, T., Öztürk, İ. (2015). Perspectives and expectations of union member and non- union member teachers on teacher unions. Eğitim Bilimleri Araştırmaları Dergisi - Journal of Educational Sciences Research, 5 (2), 191-220.

Gerzon, M.(1997). Teaching democracy by doing it. Educational Leadership, 54, 6-11.

Gökalp, M., Gönülal, E. (2017). Sınıf Yönetimi Uygulamalarında Değişim Ve Yeni Paradigmalar. Disiplinlerarası Eğitim Araştırmaları Dergisi.1(2);43-50

Güçlü, N. (2011). Sınıf Yönetimi (12. Baskı). (Ed.: Leyla Küçükahmet). Ankara: Pegem Akademi.

İlgar, L. (2007). Illköğretim öğretmenlerinin sınıf yönetimi becerileri üzerine bir araştırman. Yayımlanmamış doktora tezi, İstanbul Üniversitesi Sosyal Bilimler Enstitüsü, İstanbul.

Karge, B.D. (1993). Beginning Teachers: In Danger of Attrition. American Educational Research Association, Atlanta, GA, (ERIC Document Reproduction Service No. Ed 360281).

Kırbaş, Ş., Atay, A. (2017). Sını Öğretmenlerinin Sınıf Yönetiminde Yaşadığı Sorunlar Ve Çözüm Önerileri. 12/28, 517-538.

Korkut, K., Babaoğlan, E. (2010). Sınıf öğretmenlerinin sınıf yönetimi becerisi. Dumlupınar Üniversitesi Sosyal Bilimler Dergisi. 26,146-156.

Lemlech, J. K. (1991). Classroom Management Methods and Techniques for Elemantry and Secondary Teachers. Waveland Press: Illinois, USA.

Malmgren, K. W., Trezek, B. J., Paul, P. V. (2005). Models of classroom management as applied to the secondary classroom. The Clearing House: A Journal of Educational Strategies, Issues, and Ideas, 79(1), 36-39.

MEB, (2017). Öğretmenlik mesleği genel yeterlilikleri. Öğretmen Yetiştirme ve Geliştirme Genel Müdürlüğü. Ankara.

Merrett, F., Wheldall, K. (1993). How do teachers learn to manage classroom behaviour? A study of teachers' opinions about their initial training with special reference to classroom behaviour management. Educational Studies, 19 (1), 91-106.

Miles, M, B., Huberman, A. M. (1994). Qualitative data analysis: An expanded Sourcebook. (2nd ed). Thousand Oaks, CA: Sage.

Nazlı, K. (2015). Sınıf öğretmenlerinin sınıf yönetiminde karşılaştıkları disiplin sorunları, nedenleri ve öğretmenlerin bu sorunlarla baș etme yöntemlerinin değerlendirilmesi. Yüksek Lisans Tezi, Zirve Üniversitesi Sosyal Bilimler Enstitüsü.

Neuman, W. L., Robson, K. (2014). Basics Of Social Research. Toronto: Pearson Canada.

Özgan, H. Yiğit, C. Aydın Z. ve Küllük M, C. (2011). İlköğretim okulu öğretmenlerinin sınıf yönetimine ilişkin algılarının incelenmesi ve karşılaştırılması. Gaziantep Üniversitesi Sosyal Bilimler Dergisi, 10(1):617- 635.

Özgan, H. ve Yılmaz, S. (2009). Müfettişlerin öğretmenlerin sınıf yönetimindeki eksiklikleri hakkındaki görüşleri. Ahi Evran Üniversitesi Kırşehir Eğitim Fakültesi Dergisi, 10(2), 57-65.

Özgün, E. (2008). Ilköğretim birinci kademe öğretmenlerinin iş motivasyonları ile sınıf yönetim becerilerini algılama düzeyleri arasındaki ilişki. Yayımlanmamış yüksek lisans tezi, Yeditepe Üniversitesi Sosyal Bilimler Enstitüsü, İstanbul.

Patton, M. Q. (2014). Nitel araştırma ve değerlendirme Yöntemleri (M. Bütün ve S. B. Demir, çev.). Ankara: Pegem Akademi.

Manning, M. L., Bucher, K. T. (2014). Classroom Management: Models, applications, and cases. Peason.

Phelps, P.H. (1991). Helping Teachers Excel As Classroom Managers. Clearin House. 64 (4).

Recepoğlu, S., Ergün, M. (2017). Sosyal bilgiler öğretmen adaylarının sınıfı yönetebilme becerilerine ilişkin algıları. Kastamonu Eğitim Dergisi. 25 (4), 1337-1352.

Ritter, J. T., Hanocock. D. R. (2007). Exploring the relationship between certification experience levels, and classroom management of classroom teachers. Teaching and Teacher Education, 23(7), 1206-1216.

Rogers, C., Freiberg, H. J. (1994). Freedom To Learn. New York: Macmillan/Merrill.

Rosas, C., West, M. (2009). Teachers beliefs about classroom management: Pre-service and inserviceteachers' beliefs about classroom management. International Journal of Applied Educational Studies, 5(1),54-61. 
Sarıçoban, A. (2005), “Classroom Management Skills of The Language Teachers”, Journal of Language and Linguistic Studies, 1(1): $1-11$.

Sarıtaş, M. (2003). Sınıf Yönetimi ve Disiplini ile illgili Kurallar Geliştirme. L. Küçük Ahmet (Editör). Sınıf Yönetiminde Yeni Yaklaşımlar (s. 45-83). Ankara: Nobel Yayınları.

Şatoğlu, E. (2008). Ortaöğretim Kurumlarında Öğretmenlerin Karşılaştıkları Disiplin Sorunları ve Baş Etme Yolları. Yayınlanmış Yüksek Lisans Tezi, İstanbul: Yeditepe Üniversitesi, Sosyal Bilimler Enstitüsü.

Taşdan, M., Kantos, Z. E. (2007). Sınıf Yönetimi ve Disiplin. Z. Cafoğlu (Editör) . Sınıf Yönetimi (s. 9-42). Ankara: Grafiker Yayınları. Vural, B. (2004). Yetkin-ideal-vizyoner öğretmen (1. Basım). İstanbul: Hayat Yayıncılık.

Yıldırım, A., Şimşek, H. (2013). Sosyal Bilimlerde Nitel Araştırma Yöntemleri. Ankara: Seçkin Yayıncılık.

Yılmaz, N. (2008). “Dersin Akışını Bozan İstenmeyen Davranışları Yönetme Stratejilerinin İncelenmesi”. Erzincan Eğitim Fakültesi Dergisi, 10 (1), 1-38.

Yüksel, A. (2013). Sınıf öğretmenlerinin sınıf yönetimi becerilerinin değerlendirilmesi (Afyonkarahisar ili örneği). Doktora Tezi, Gazi Üniversitesi Eğitim Bilimleri Enstitüsü, Ankara. 